\title{
DR. 1957
}

DOE / NASA CONTRACTOR

DOE / NASA CR-161562

REPORT

\section{INSTALLATION PACKAGE FOR SOLAR DOMESTIC HOT WATER SYSTEM}

By Elcam, Inc.

5330 Debbie Lane

Santa Barbara, CA 93111

Under Contract NAS8-32245 with

National Aeronautics and Space Administration

MASTER

George C. Marshall Space Flight Center, Alabama 35812

For the U. S. Department of Energy

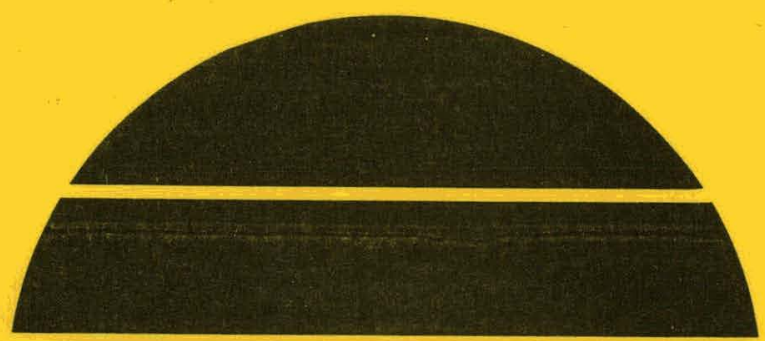

U.S. Department of Energy 


\section{DISCLAIMER}

This report was prepared as an account of work sponsored by an agency of the United States Government. Neither the United States Government nor any agency Thereof, nor any of their employees, makes any warranty, express or implied, or assumes any legal liability or responsibility for the accuracy, completeness, or usefulness of any information, apparatus, product, or process disclosed, or represents that its use would not infringe privately owned rights. Reference herein to any specific commercial product, process, or service by trade name, trademark, manufacturer, or otherwise does not necessarily constitute or imply its endorsement, recommendation, or favoring by the United States Government or any agency thereof. The views and opinions of authors expressed herein do not necessarily state or reflect those of the United States Government or any agency thereof. 


\section{DISCLAIMER}

Portions of this document may be illegible in electronic image products. Images are produced from the best available original document. 
Th1s report was prepared to document work sponsored by the United States Government. Nelther the United States nor 1 ts agents the United States Department of Energy, the United States National Aeronautics and Space Adminfstratlon, nor any federal employees, nor any of their contractors, subcontractors or their employees, make any warranty, express or 1mplied, or assume any legal liabllity or responstbllity for the accuracy, completeness, or usefulness of any information, apparatus, product or process disclosed, or represent that its use would not Infringe privately owned rights. 


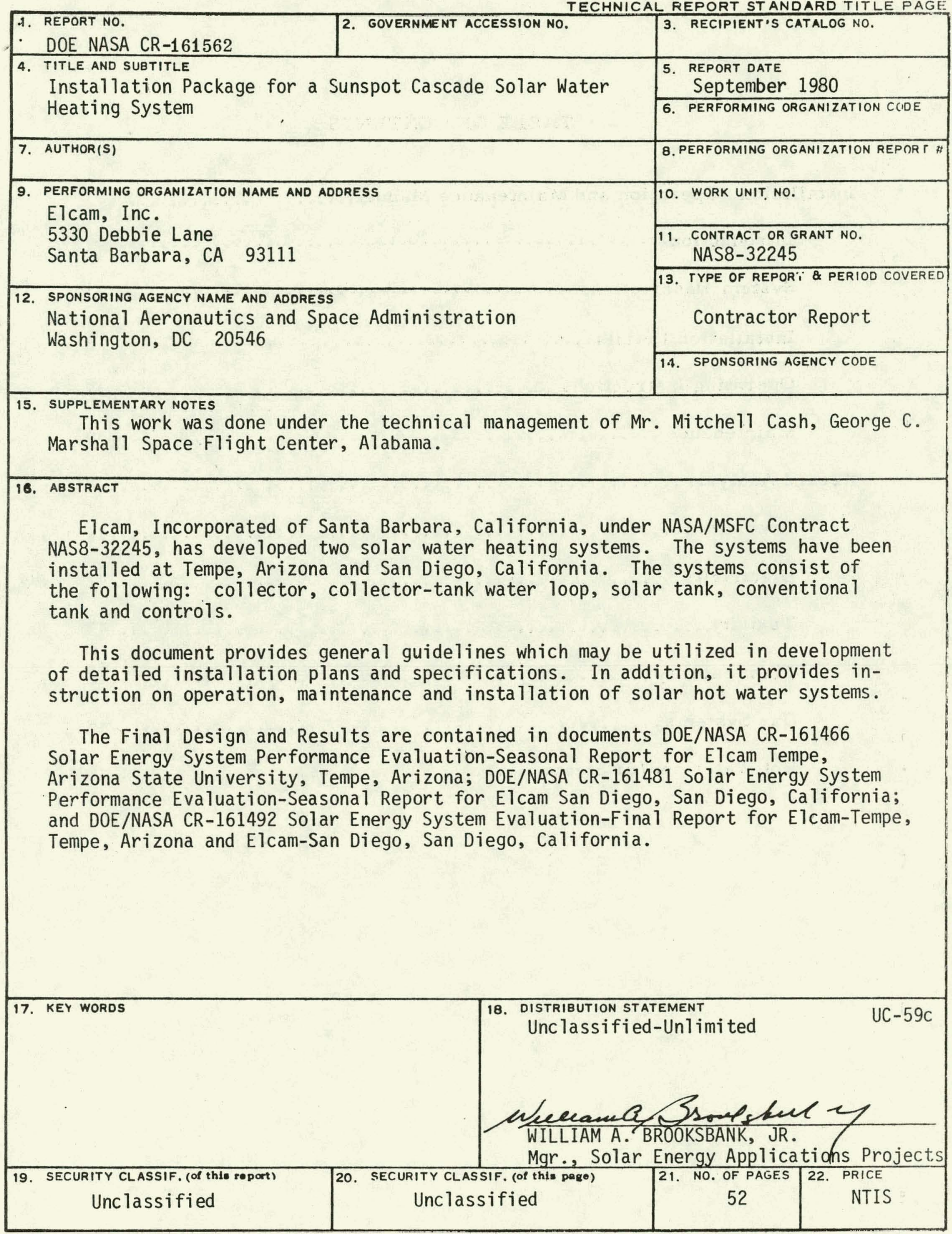


THIS PAGE

\section{WAS INTENTIONALLY LEFT BLANK}




\section{TABLE OF CONTENTS}

In tallation, Operation and Maintenance Manual................

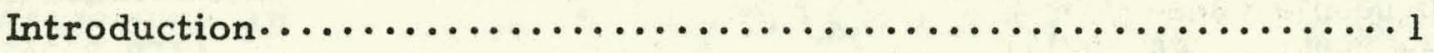

System Descriptions $\ldots \ldots \ldots \ldots \ldots \ldots \ldots \ldots \ldots \ldots \ldots \ldots \ldots \ldots \ldots \ldots \ldots \ldots \ldots \ldots \ldots \ldots \ldots \ldots \ldots$

Installation Details $\ldots \ldots \ldots \ldots \ldots \ldots \ldots \ldots \ldots \ldots \ldots \ldots \ldots \ldots$

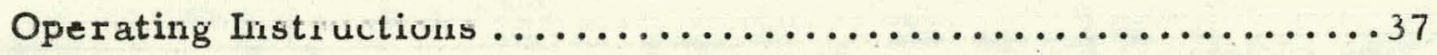

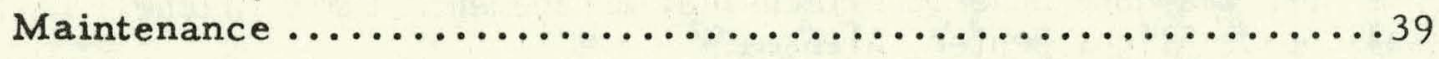

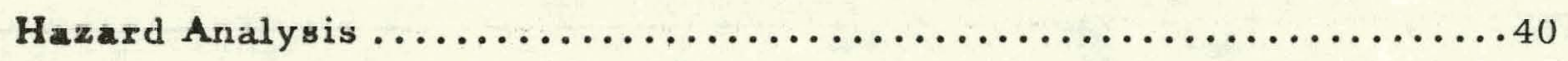

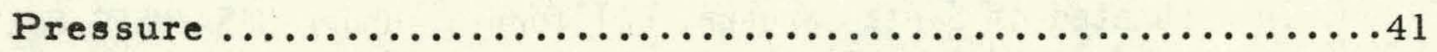

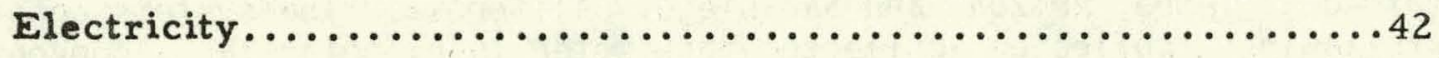

Toxicity....................................

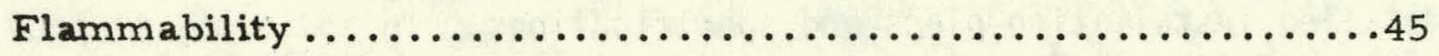

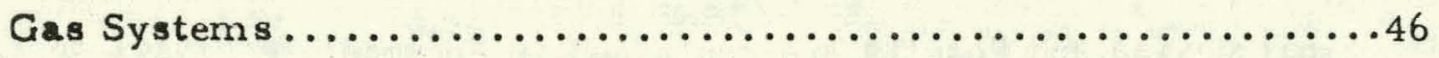

Hot Water and/or Steam........................... 


\section{INSTALLATION, OPERATION \& MAINTENANCE MANUAL}

\subsection{INTRODUCTION}

This manual is provided as a guide to the proper installation and use of SUNSPOT CASCADE Solar Water Heating Systems. The installer should thoroughly familiarize himse! $f$ with this manual before beginning any installation operations.

The manual is divided into five sections as follows:

1.0 INTRODUCTION

2.0 SYSTEM DESCRIPTIONS

3.0 INSTALLATION DETAILS

4.0 OPERATING INSTRUCTIONS

5.0 MAINTENANCE

\subsection{SYSTEM DESCRIPTIONS}

Figure 2.1 illustrates the standard dual tank SUNSPOT DUAL configuration. Potable water is circulated through the collector(s) and returned to either the solar tank or to the conventional tank. Collector loop water is drawn only from the tank to which solar heated water is being returned.

The CASCADE Autocontrol senses the temperatures of the collector $\left(T_{C}\right)$, the solar tank $\left(T_{S}\right)$ and the conventional tank $\left(T_{E}\right)$. These temperatures are compared with each other, and with three internally generated IOM MANUAL 


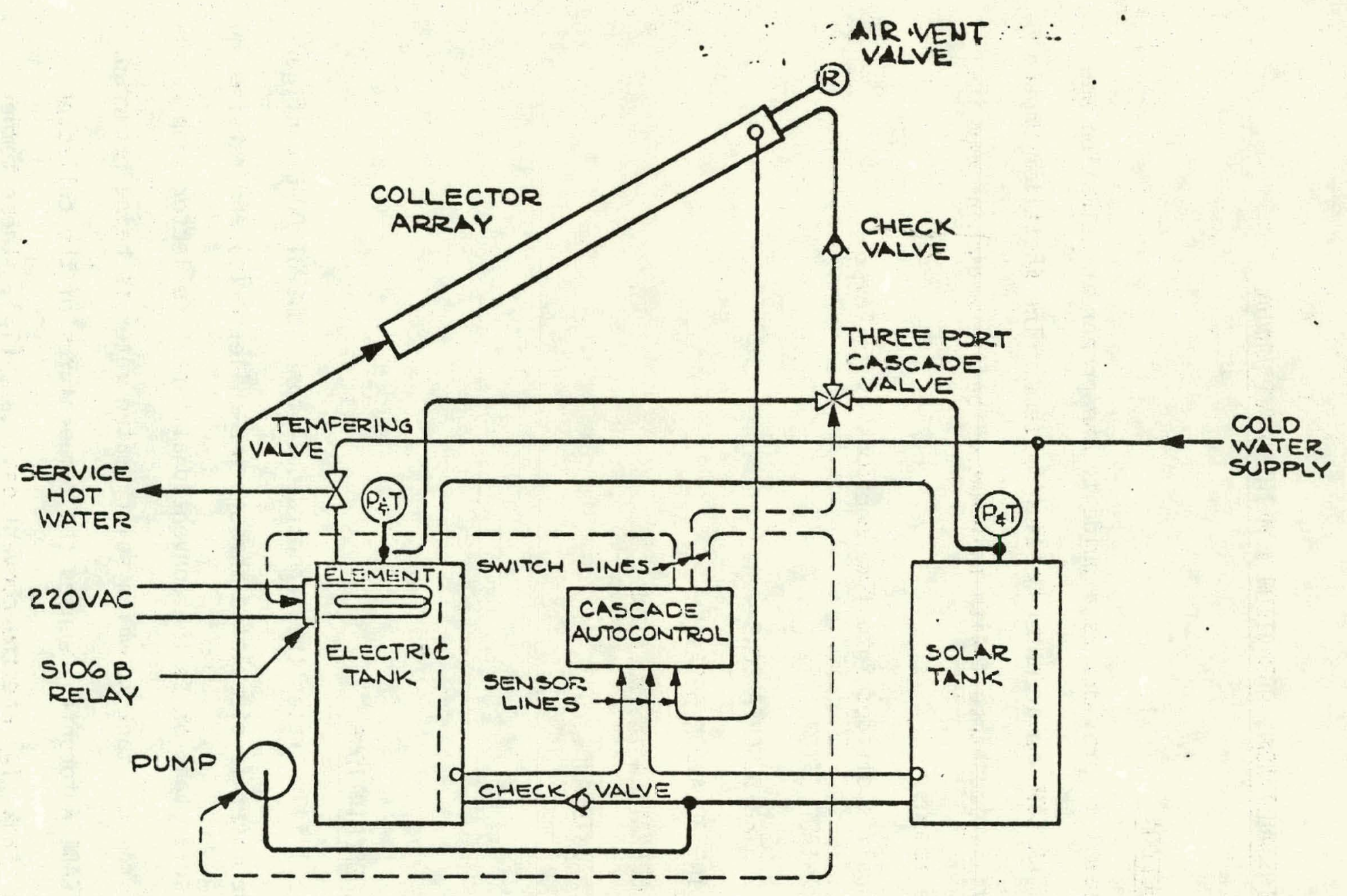

FIGURE 2.1 DUAL TANK CONFIGURATION

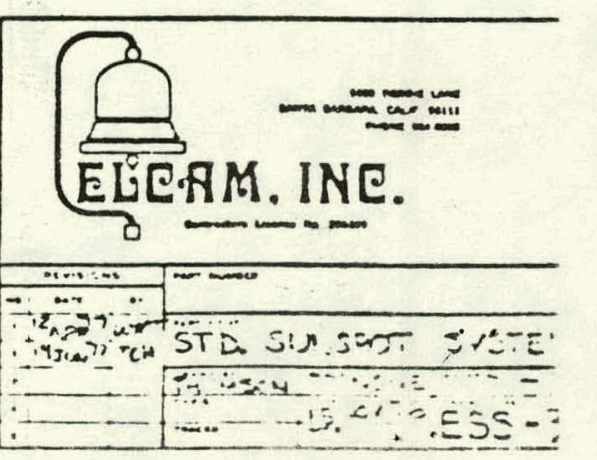


reference temperatures: $T_{M A X}$ and $T_{\text {MIN }}$, the highest* and lowest allowable conventional tank temperatures, and $T_{F}$, which is set just above freezing temperature (usually $34.5^{\circ} \mathrm{F}$.).

The results of these comparisons are as follows:

a. The circulator pump is switched ON or OFF.

b. The CASCADE valve returns solar heated water to one tank or the other.

c. The conventional energy flow is interrupted or governed by its own thermostat.

In its standard form, the CASCADE Autocontrol incorporates a

FROST CYCLE. This is appropriate to prevent freeze damage to the collector(s) in temperate climates by circulating hot water through the collectors to keep $T_{C}>T_{F}$. In $\mathrm{cl}$ imates where freezing occurs more than 30 days per year, or where the low temperature is routinely under $25^{\circ} \mathrm{F}$., the FREEZE CONTROL option is specified. This configuration is illustrated in Figure 2.2.

When $T_{C} \leq T_{F}$, the FREEZE CONTROL isolates the collector loop (from. mains water pressure), and drains it. When ${ }^{T} C$ returns to its normal operating range, the collector loop is automatically refilled. In the event of a power failure, the FREEZE CONTROL performs as if $T_{C} \leq T_{F}$.

In some cases the solar tank top may be higher or lower than the conventional energy tank top. This could result from either different tank sizes or different tank bottom heights. In these cases the difference in head between the tanks may result in improper water flow. For this reason a second CASCADE valve is installed, as shown in Figure 2.3.

* Note: In some circumstances, the conventional tank temperature may

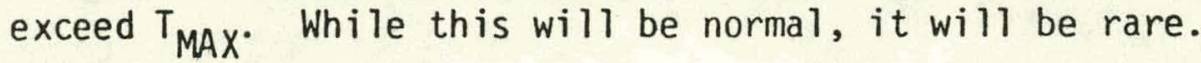

IOM MANUAL 


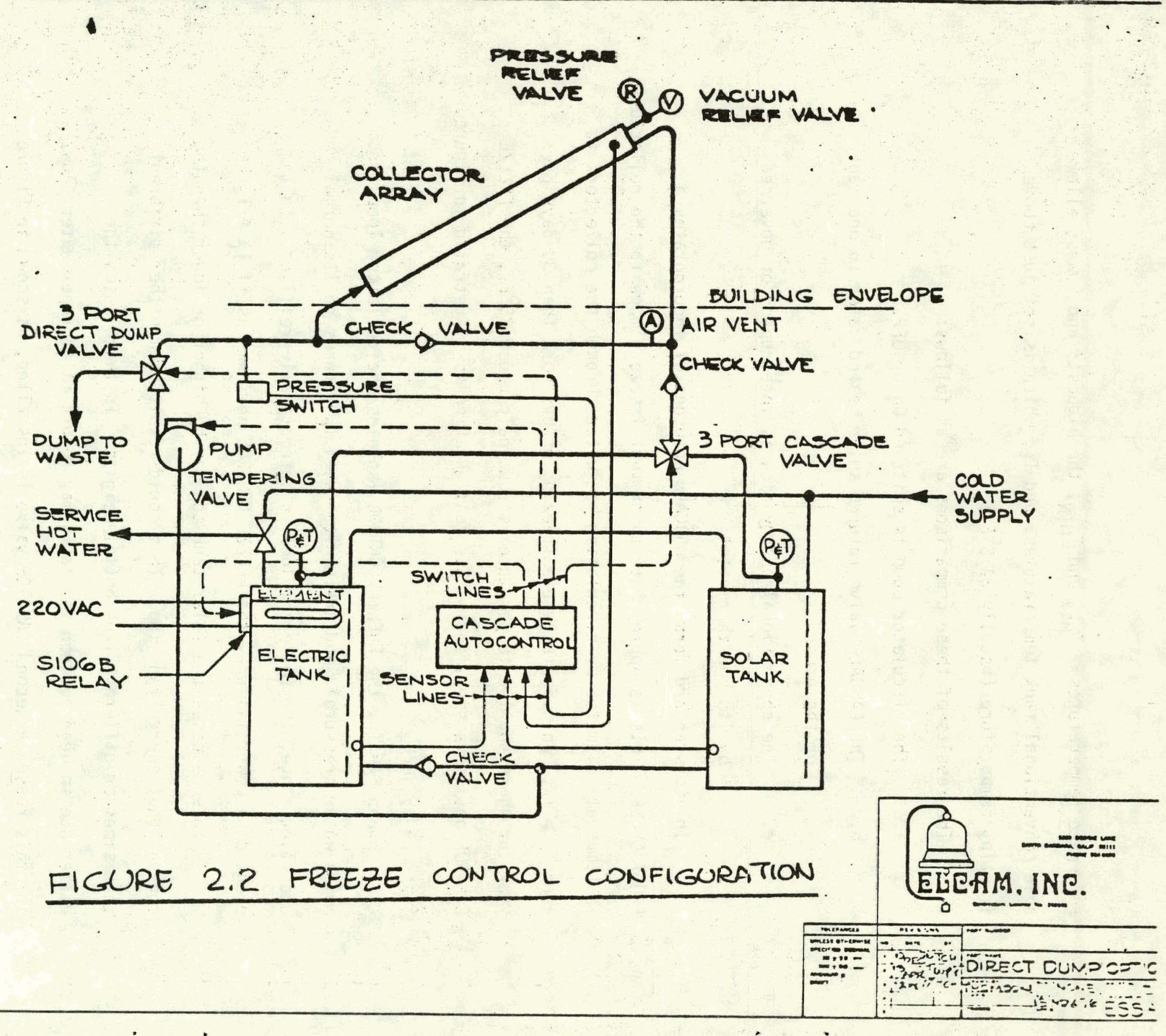


PURGE \& PRESSURE RELIEF VALVE

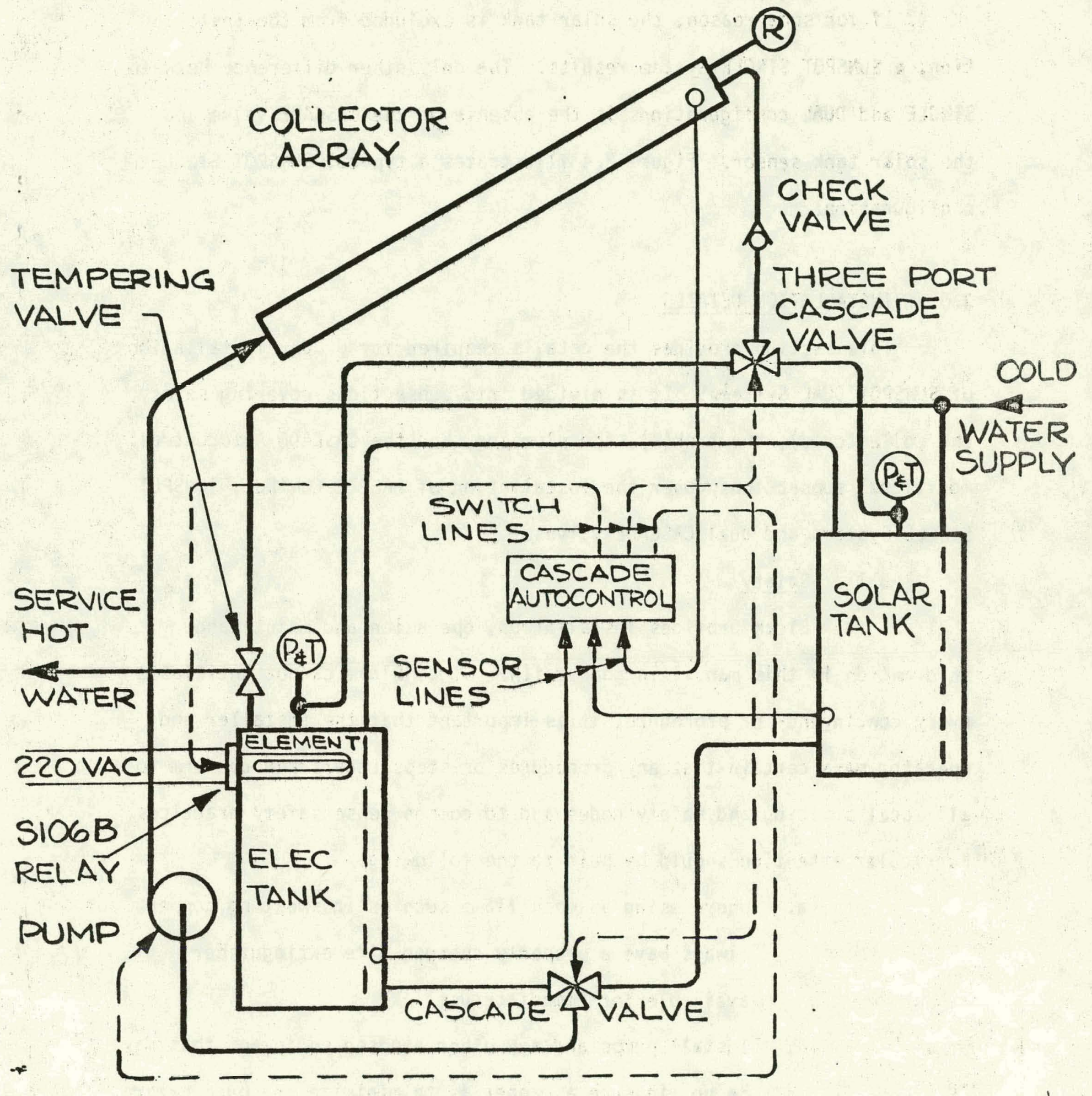

FIGURE 2.3 DUAL CASCADE VALVE CONFIGURATION 
If for some reason, the solar tank is excluded from the installation, SUNSPOT SINGLE System results. The only other difference between SINGLE and DUNL configurations is the absense of the CASCADE valve and the solar tank sensor. Figure 2.4 illustrates a typical SUNSPOT SINGLE configuration.

\subsection{INSTALLATION DETAILS}

This section provides the details required for proper installation of SUNSPOT DUAL Systems. It is divided into subsections covering safety, the collector(s), the tank(s), the plumbing, and the CASCADE Autocontrol. Additional subsections cover the installation of FREEZE CONTROL, SUNSPOT SINGLE Systems and dual CASCADE valves.

\subsection{Safety}

Elcam provides installation, operation and maintenance information in this manual in good faith. Since Elcam cannot anticipate every contingency or procedure, it is important that the installer and operator make certain that any procedures or steps undertaken conform to all local bullding and safety codes and to common sense safety practices. Particular attention should be paid to the following:

a. Where using an open flame such as in sweating copper, always have a properly charged fire extinguisher avail lable for immediate use.

b. Install pumps and any other exposed equipment that may be hot in such a manner as to minimize any burn hazard.

IOF MANUAL 


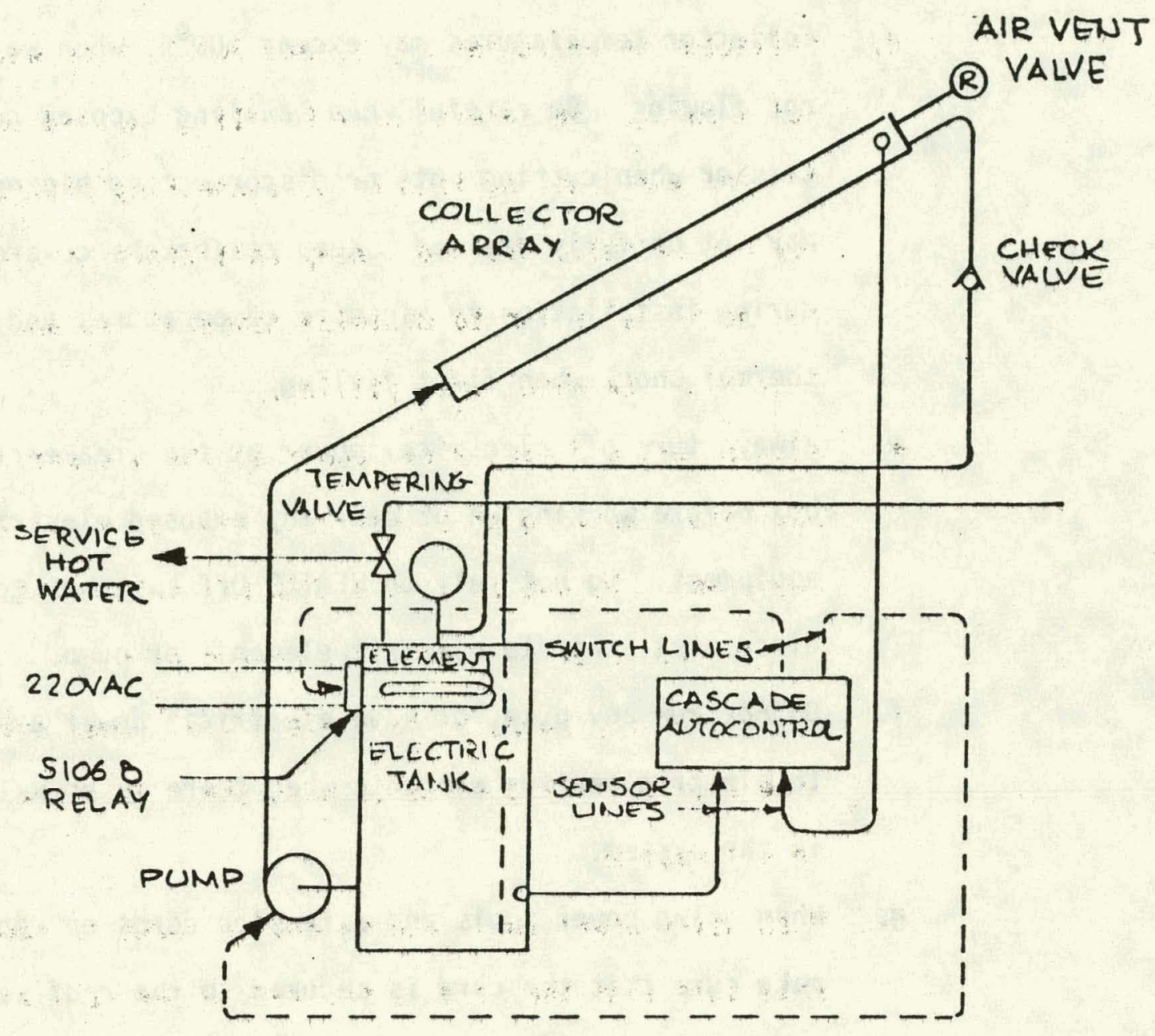

FIGURE 2.4 SINGLE TANK CONFIGURATION

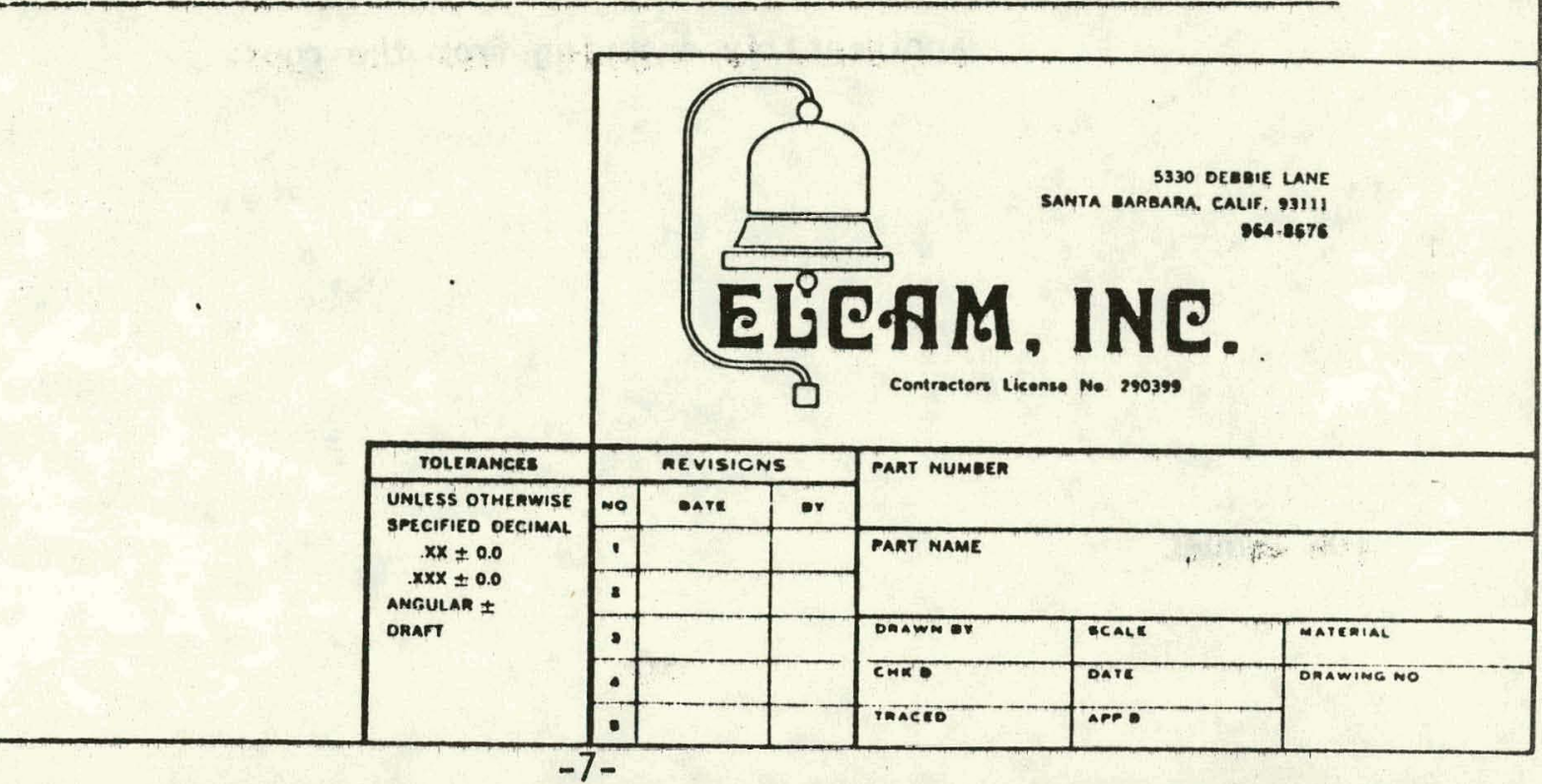


c. Make sure that all plumbing lines are installed so that they may be fully drained.

d. Collector temperatures may exceed $300^{\circ} \mathrm{F}$. when water is not flowing. Be careful when handling exposed collectors or when cutting into or disconnecting piping that may not be fully drained. Keep collectors covered during installation to minimize temperatures and thermal shock when first filling.

e. Always turn off electrical power at the breaker/fuse box before working on or near any exposed electrical equipment. Do not rely on HEATER OFF switches to disconnect power to electric elements or pump.

f. Do not run any pump, or have electrical power available to electric heating elements when there is no water in the system.

9. When using power tools and extension cords on roofs, make sure that the cord is secured to the roof so that its weight will not cause an unattended tool to be dragged off the roof. Ensure that all unattended tools are placed in such a way as to avoid their accidentally dropping from the roof. 


\subsection{Collector Installation}

The following precautions should be observed when installing

the collectors:

a. Caution should be exercised when handling collectors, particularly in handling them on a roof. In most instances two persons can handle a collector satisfactorily, but for high or steep roofs a third person and/or a lift may be necessary.

b. When exposed to the sun without water flow, the cover, absorber, and pipes can become very hot.

c. The collector cover is durable and can withstand a degree of rough handling, but this should be held to a minimum. Whenever possible, transport and store the collector with its face up, or on its edge.

d. When it is necessary to stack collectors, place them one above the other, with all covers facing up. Protect the covers from damage by using a wooden spacer between each collector.

\subsubsection{Collector Orientation: Because sufficient roof area} may not always be available to orient the collector(s) in a standard manner, a variety of collector groupings has been analysed. Figure 3.2.1.1 illustrates these orientations and their correct plumbing interconnections. Any of the groupings is satisfactory, and may be chosen for space, esthetics or any other reason.

IOM MANUAL 

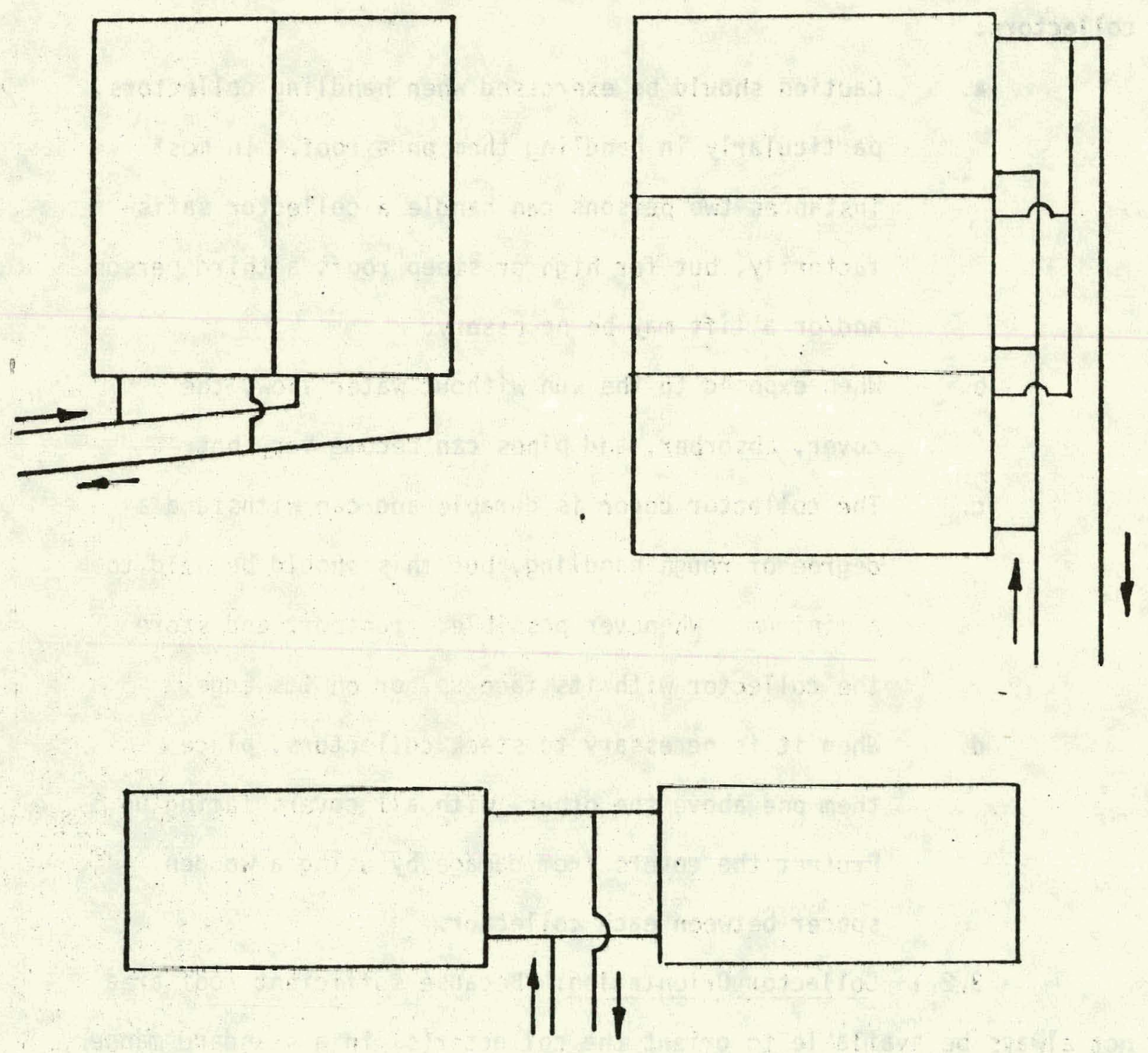

FIGURE 3.2.1.1.

- collector interconnegtons

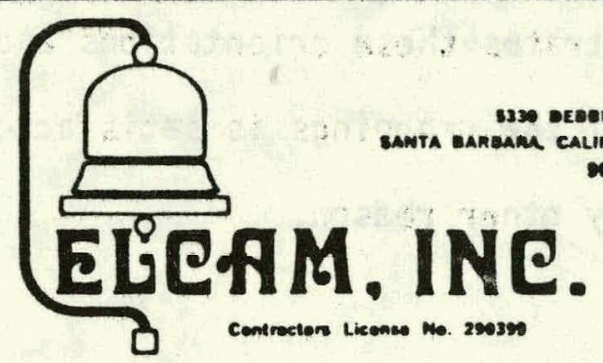

\begin{tabular}{|c|c|c|c|c|c|c|}
\hline relreavers & \multicolumn{3}{|c|}{ DEVISICNS } & \multicolumn{3}{|c|}{ PART MUMAER } \\
\hline \multirow{6}{*}{ 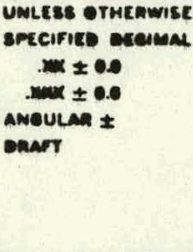 } & me & Dare & or & & & \\
\hline & ' & & & \multirow{2}{*}{\multicolumn{2}{|c|}{ PART MAME }} & \\
\hline & a & & & & & \\
\hline & - & & & onawn or & ecale & WATERIAL \\
\hline & •• & & & CME & DATE & ONAWING ME \\
\hline & • & & & TACACE & Appo & \\
\hline
\end{tabular}


While it is advisable to always install collectors so that they may drain, this is essential for the correct operation of the FREEZE CONTROL option. To insure proper drainage, always install the collectors so that either the headers or the waterway tubes are horizontal. A tolerance of up to $1 / 16$ in. per foot can be accommodated.

NOTE: The headers and waterways are parallel to the short and long edges of the collector box.

\subsubsection{Collector Interconnections: SUNSPOT Collectors} are designed to be fed from the lower connector and to exhaust from the higher connector. Multiple collectors should be plumbed in PARALLEL to achieve highest system efficiency. Figure 3.2.1.1 illustrates several typical collector interconnections. Always ensure that interconnection plumbing runs are self draining. Also ensure that the same TOTAL HEAD (STATIC plus DYNAMIC) is experienced by each collector. This is essential

- * in order to achieve equal flow rates through each collector in a given system. The equal. TOTAL HEAD requirement may be achieved by correct interconnection practices as shown in Figure 3.2.1.1. The general rule that

IOM MANUAL 


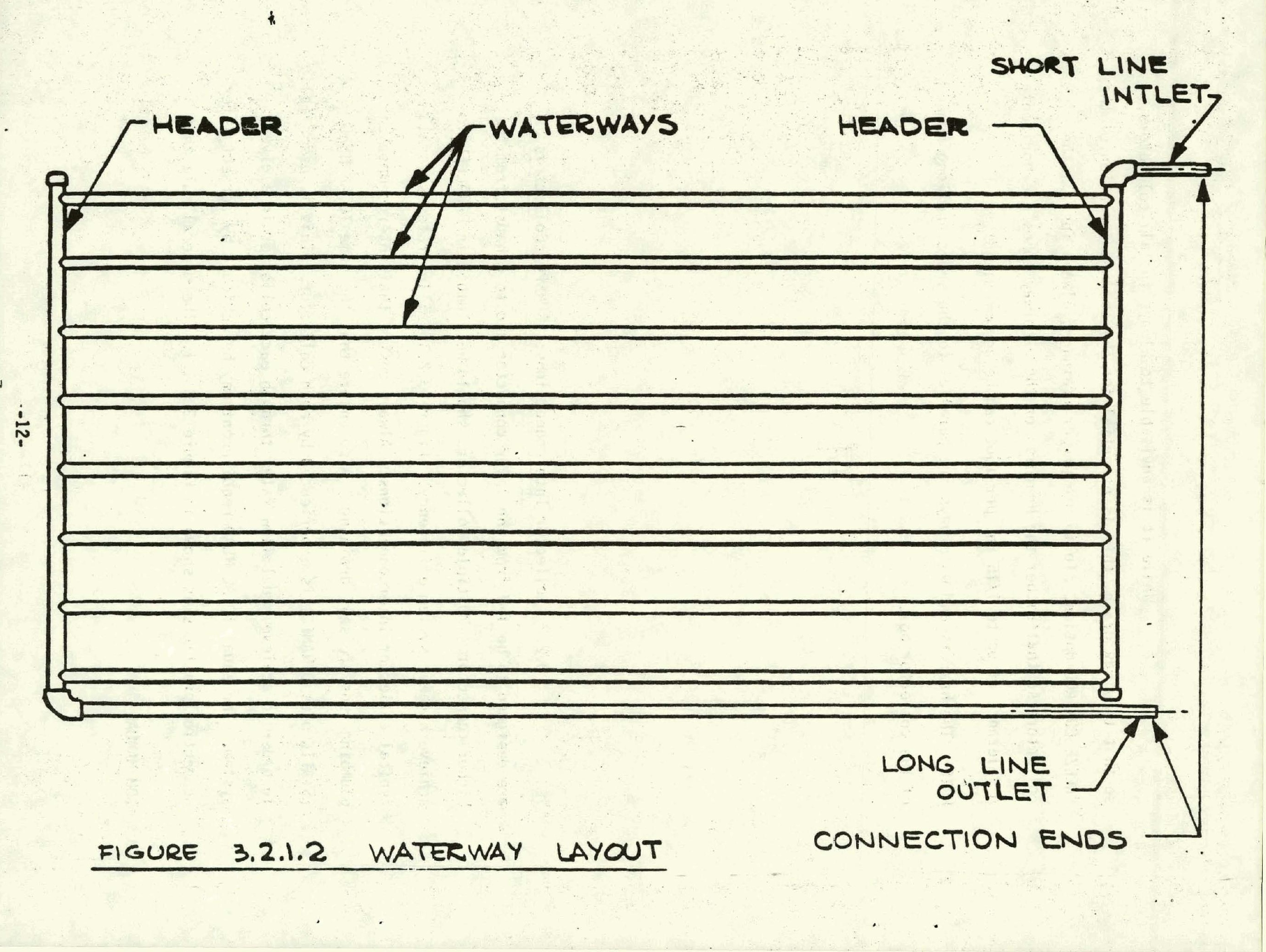


applies here is:

FEED ALL COLLECTORS FROM A COMMON LOW POINT AND EXHAUST ALL COLLECTORS TO A COMMON HIGH POINT.

NOTE: If more than four collectors are required, the circulator specification must be changed.

\subsubsection{Mounting Collectors: SUNSPOT Collectors have been} designed for mounting on all types of roof construction, or on racks. Rack mounting is the simplest, since the collector is mounted directly on the rack structure, as shown in Figure 3.2.3.1.

The collector back should be raised from one to two inches from the roof surface. This will provide a breathing space between the roof surface and the collector, and will also prevent any high roof spots from stressing the collector back. For shake, shingle, asbestos cement, built up and asphalt tiles or flat tiled roofs, a short $2 \times 4$ redwood or aluminum spacer is adequate. A longer spacer is required for mounting collectors on Spanish tiles. Both mounting techniques are illustrated In Figure 3.2.3.2.

3.2.4 Securing Collectors: The flange on the collector box is provided with a scribed line to be used as the center location of holes to be drilled to accomodate tie down lagscrews. These holes may be made at any of four to six locations on the periphery of the collector. The lag screws should be $1 / 4^{\prime \prime}$ in diameter, and must be long enough to reach well into the roof structure beneath the roof cladding. Figure 3.2.3.2. illustrates a typical cross section.

IOM MANUAL 


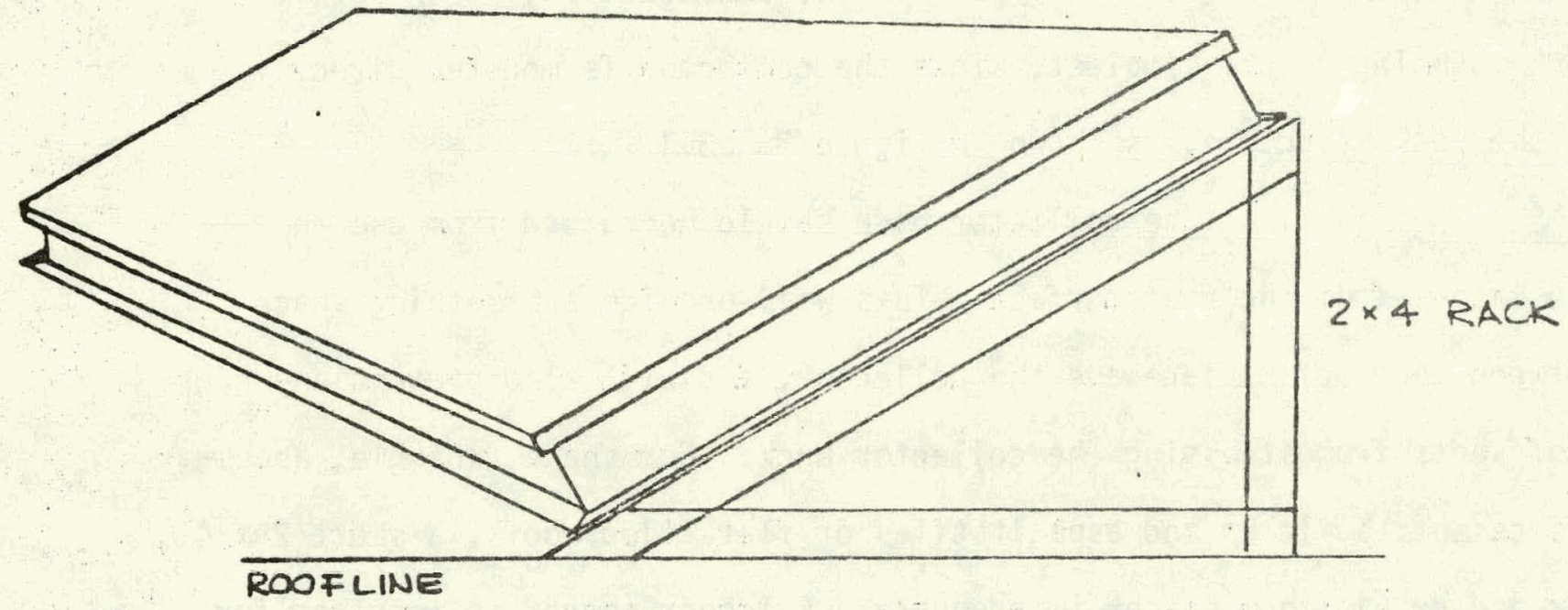

FIGURE 3.2.3,1. RACK MOUNTING

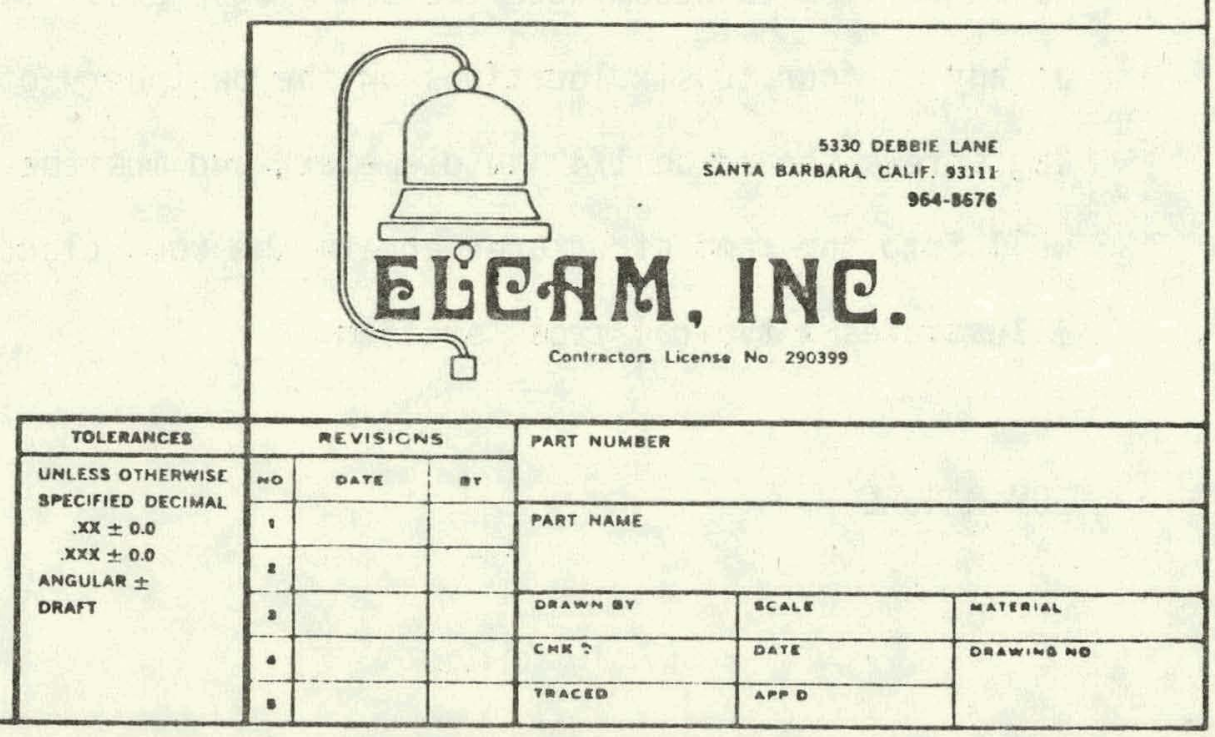




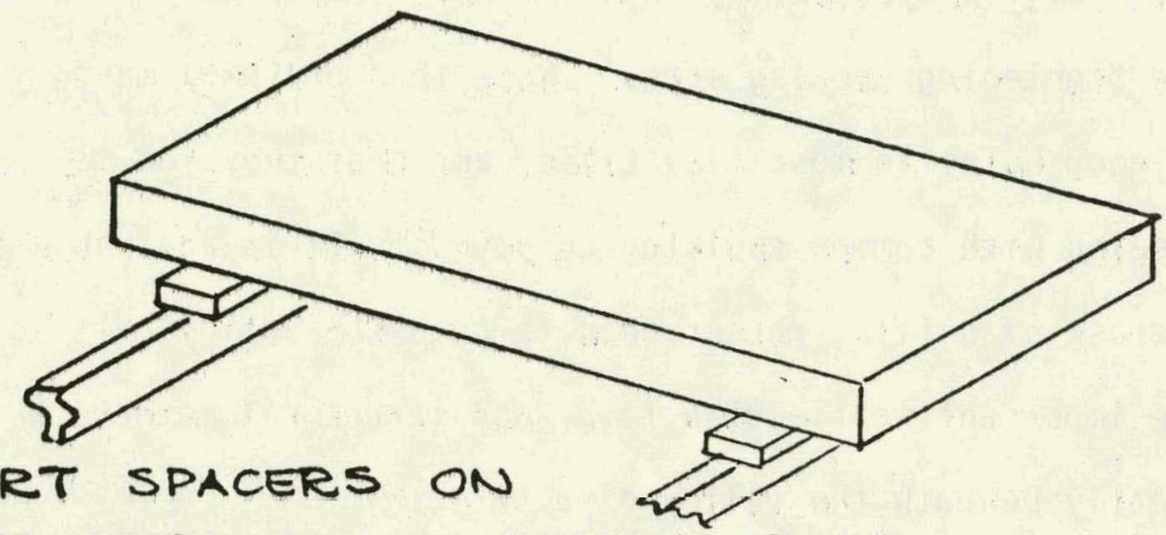

SHORT SPACERS ON

Flat SURFACB OF PITCHED ROOF.

NOTE THAT TIE DOWN LAGSCREWS SHOULD

PENETRATE ROOF STRUCTURAL MEMBERS BENEATH SPACERS

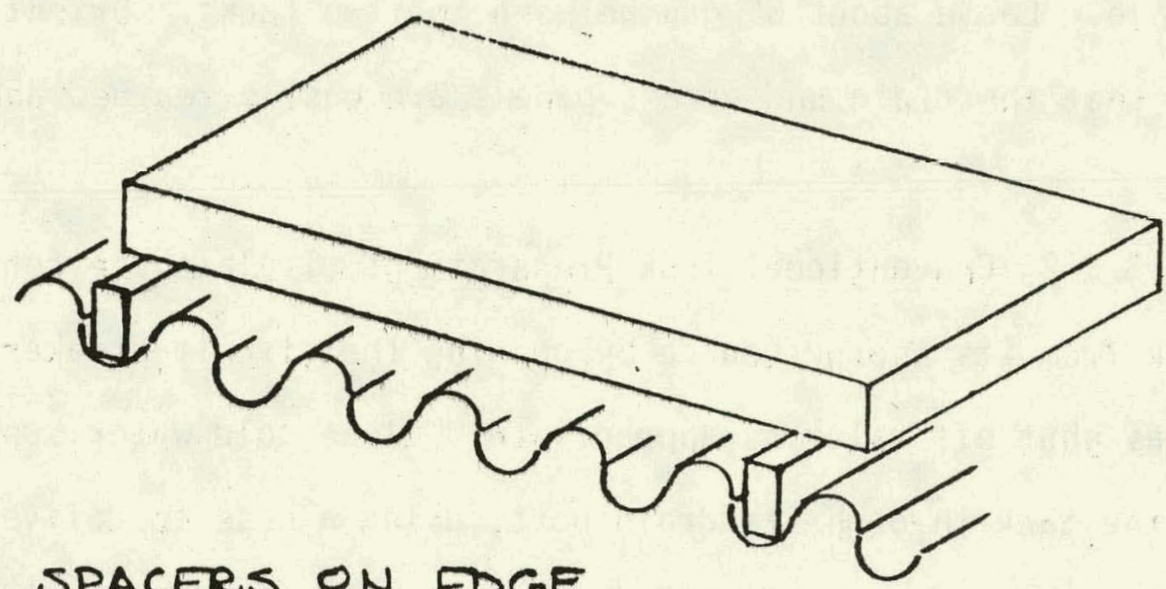

LONG SPACERS ON EDGE

IN VALLEYS OF SPANISH TILE ROOF

FIGURE 3.2 .3 .2 .

$*$

ROOF MOUNTING

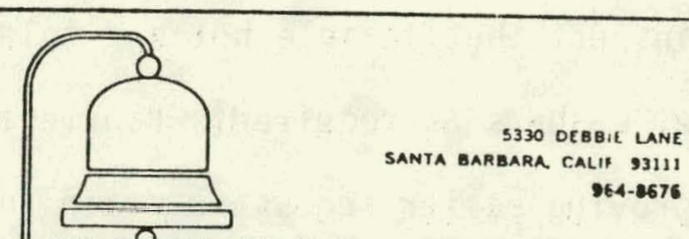

\begin{tabular}{|c|c|c|c|c|c|c|}
\hline TOLERANCES & \multicolumn{3}{|c|}{ REVISICNS } & \multirow{2}{*}{\multicolumn{3}{|c|}{ PART NUMEER }} \\
\hline \multirow{6}{*}{$\begin{array}{l}\text { UNLESS OTHE AWISE } \\
\text { SPECIFIED DECIMAAL } \\
\quad \times X \pm 0.0 \\
\quad X X X \pm 0.0 \\
\text { ANGULAR } \pm \\
\text { DRAFT }\end{array}$} & no & Dave & $\bullet r$ & & & \\
\hline & ' & & & \multirow{2}{*}{\multicolumn{2}{|c|}{ PART NAME }} & \\
\hline & 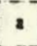 & & & & & \\
\hline & a & & & DAAWN EY & ecale & matanial \\
\hline & $\bullet$ & & & $C W \times D^{\circ}$ & -atis & DAATINOTO \\
\hline & - & & & TACACD & APPO O & \\
\hline
\end{tabular}


In order to make a weatherproof tie down, always predrill a pilot hole for the lag screw and inject a generous bead of a qualitysealant (e.g. polysulphide) into the hole immediately prior to inserting and tightening the lag screw. Note that ordinary masonry bits will produce good holes in most clay tiles, and that they too may be adequately sealed with common caulking compounds. It is advisable to drill through the crest of a tile, rather than through the valley. It is however, more important to tie down to a roof structural member, which could be directly beneath the valley of a tile.

\section{3 Tank Installation}

3.3.1. Solar Tank Location and Orientation: Remove the solar tank from its carton, and locate it as close to the conventional tank as feasible. Leave about 6" gap between the two tanks. Orient the solar tank so that the drain and access panels are easily reached and removed.

\subsubsection{Conventional Tank Preparation: Isolate the con-} ventional tank from $i$ ts energy source by opening the circuit breakers or closing the gas shut off valve as appropriate. Closc cold water supply valve. Drain the tank through its drain port, using a hose to deliver the hot water to a safe area. Draining may be facilitated by opening the pressure and temperature $(P / T)$ relief valve on the tank top. Remove and inspect the flexible hot and cold lines from the tank. Replace gaskets or washers as required. Reorient the conventional tank if necessary, to provide easier access to drain and access covers.

IOM MANUAL 


\section{$3.4 \quad$ Plumbing}

Refer to Figure 2.1 for illustration of the $i$ deas discussed below. For non-standard SUNSPOT installations (e.g. SUNSPOT SINGLE, FREEZE CONTROL or DUAL CASCADE VALVES) refer to appropriate subsection

\section{$3.4 .1,3.4 .2,3.4 .3$.}

3.4.1 Tank Plumbing: Remove the COLD supply flexible pipe and replace it with a TEE fitting. The branch of the TEE will feed the COLD port of the TEMPERING VALVE. Using $3 / 4 "$ flexible and rigid copper, connect this TEE to the COLD nipple on the solar lank. Connect the HOT nipple on the solar tank to the COLD nipple on the conventional tank using 3/4" fiexible and rigid copper as required. Using rigid $3 / 4 "$ copper, connect the HOT nipple of the conventional tank to the HOT port of the tempering valve. Note that the tempering valve must be located at least 6 " below the top of the conventional tank, and should be conveniently accessible.

WARNING - REMOVE CORE FROM TEMPERING VALVE BEFORE APPLYING HEAT.

With rigid 3/4" copper, connect the branch of the TEE (installed in the COLD line) to the COLD port of the tempering valve. Finally, the MIXED port of the tempering valve is connected to the HOT pipe leading into the house, using a flexible 3/4" copper pipe. Install and tighten tempering valve core, and set the valve to $140^{\circ} \mathrm{F}$.

3.4.2 Tank Modifications: Prior to connecting the tanks into the collector loop, their connections must be modified as follows. These modifications apply to both solar and conventional tanks. 
Remove the drain valves and nipples from both tanks. After opening fully, some drain valves require a sharp pull to engage a reverse (left hand) thread which is used for removal. Make up two new drain assemblies/collector loop supply lines as shown in Figure 3.4.2.1.

Screw a 2 " long $3 / 4^{\prime \prime}$ brass nipple into the drain port. Thread a $3 / 4^{\prime \prime}$ brass TEE branch out this nipple. Into one end of the TEE, assemble the drain nipple and valve. Into the other end, thread a $1 / 2^{\prime \prime} \times 3 / 4^{\prime \prime}$ copper $\times$ male NPT adapter*.

Figure 3.4.2.2. illustrates how the collector loop returns are plumbed into the tanks. To make up these returns, remove the $P / T$ valve from the conventional tank. If the temperature sensing bulb is at least 4" long it may be reused. When reassembled, this bulb must be inside the tank shell. Install long stenuned $P / T$ valves in both tanks through $3 / 4 "$ brass TEE and 2" brass nipples: In the branch of each TEE, install a $1 / 2^{\prime \prime} \times 3 / 4^{\prime \prime}$ copper $\times$ male NPT adaptor. ${ }^{\star}$ Plumb both P/T exhausts according to local codes.

3.4.3 Collector Loop: Wherever possible, install insulation on pipes by slipping on before sweating. Start at the collector loop feed points which are adjacent to the modified tank drains. Connect these feed points with $1 / 2^{\prime \prime}$ copper*. Include a $1 / 2^{\prime \prime}$ * copper TEE** approximately midway between the feed points, and a $1 / 2^{\prime \prime}$ teflon seated check valve* between this TEE and the conventional tank feed. The check valve should be installed in a horizontal section of copper, and should permit flow OUT of the conyentional tank,

* Note: Unless the collector loop exceeds 100 feet in length, $1 / 2^{\prime \prime}$ plumbing is adequate. For loops of between 100 feet and 200, use 3/4" sizes throughout.

**Note: If the drain/tank top distances are different, or if the tank heads applied to the drains are different, this TEE may have to be replaced by a CASCADE valve. Refer to Section 3.9 for details.

IOM MANUAL 


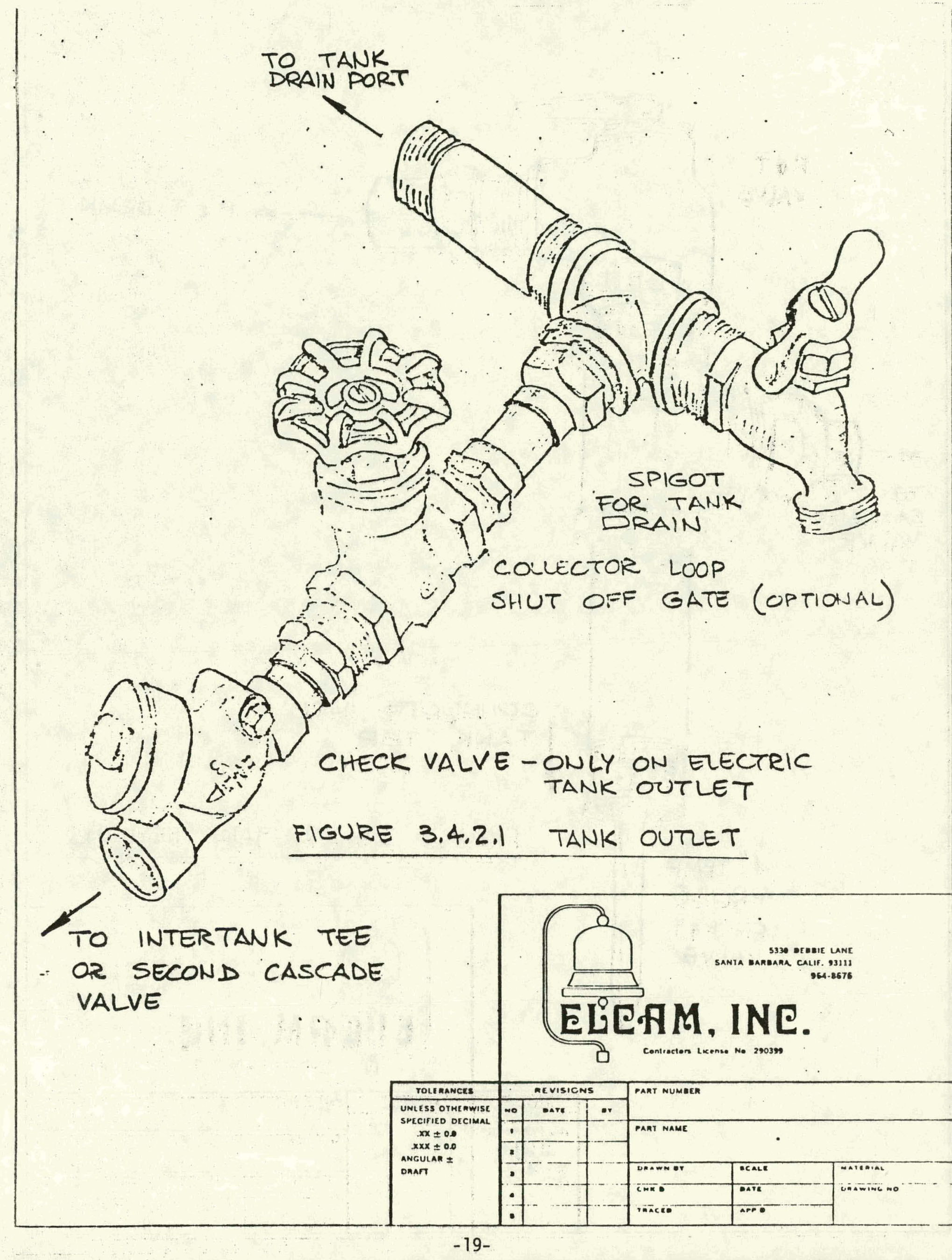




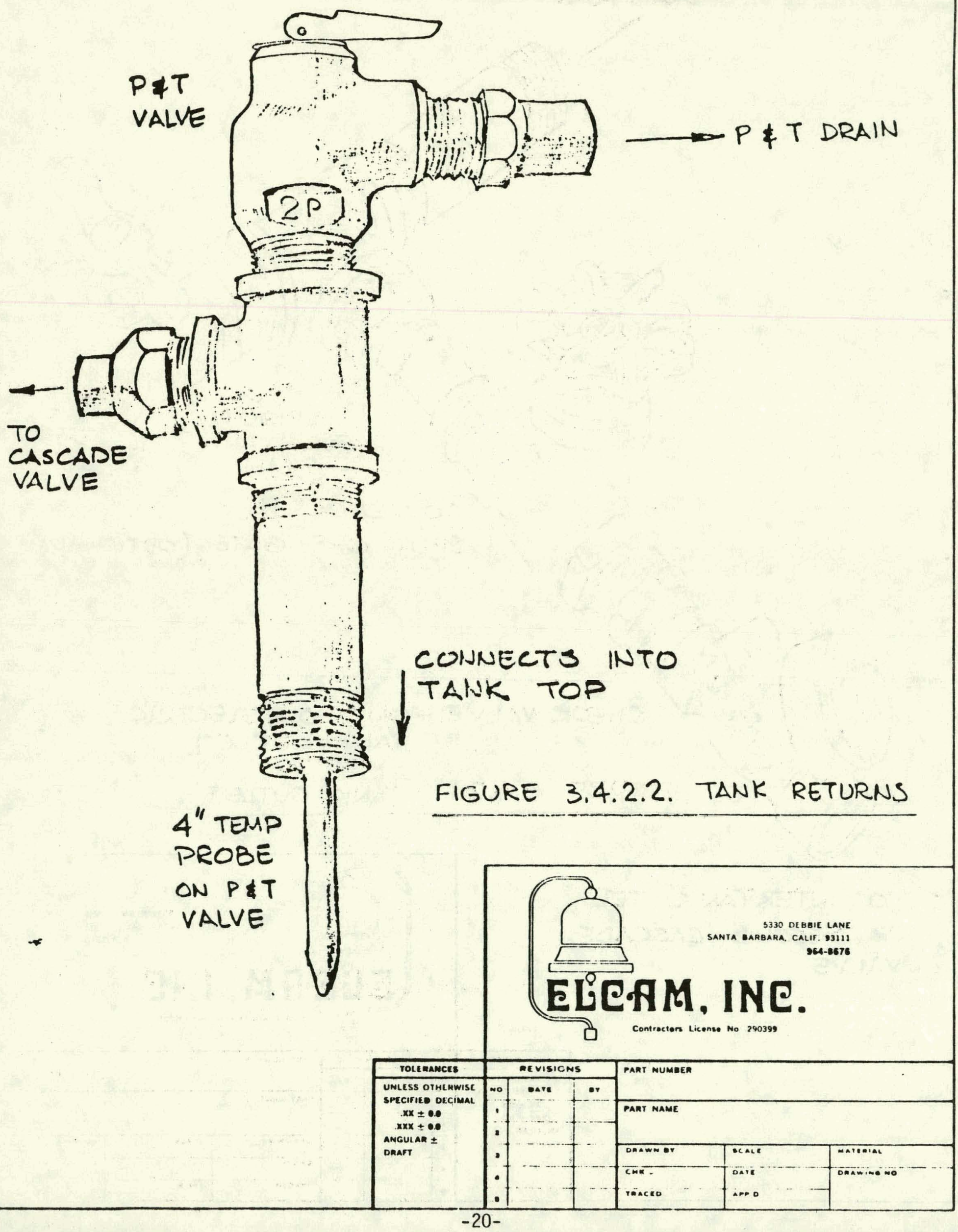




\section{4 (Addition)}

Note: Although it is not essential, good plumbing practice suggests the use of five shut off gate valves, one on the feed and drain lines of each tank, and one on the drain line which should TEE into the lowest point of the collector loop.

IOM MANUAL 
The branch of this TEE should be oriented toward a wall or structure suitable for mounting the pump. Assemble the flange fittings onto the pump. If shut off flanges are not supplied, use a $1 / 2^{1 "}$ * gate valve on each side of the pump. The pump should be installed in accordance with the manufacturers instructions, and never at the low point of the collector loop. Because the collector loop is pressurized, pump performance is not sensitive to its vertical location in the loop. Connect the suction flange of the pump to the TEE branch mentioned above, using a flexible pipe as a part of this section. The feed flange of the pump is connected to the collector input lines. The air vent valve is installed at the high point of the collector loop in the branch of a TEE. It must be installed vertically. A pressure relief valve is installed near the air vent valve. I ts exhaust must be plumbed to a safe area according to local codes.

The return from the collectors should be brought down to a point on the wall or structure just above and between the two tanks. Connect the two tank returns together, including the CASCADE valve at approximately the midway point.

IMPORTANT: The valve body (brass section) should be below the electrical housing.

The AUTO/MANUAL lever should be placed in MANUAL prior to applying any heat.

Port A should be connected to the conventional tank.

* Note: Unless the collector loop exceeds 100 feet in length, $1 / 2$ " plumbing is adequate. For loops of between 100 feet and 200, use 3/4" sizes throughout.

IOM MANUAL 
Port B should be connected to the solar tank.

Port $A B$, should be connected to the collector return, using a flexible connector. A $1 / 2^{\prime \prime}$ teflon seated check valve should be installed in a horizontal section of pipe between port $A B$ and the collector return. This check valve must permit flow TOWARD the CASCADE valve and the tanks.

Figure 3.4.3.1 illustrates the CASCADE valve plumbing. Support all plumbing at $6^{\prime}$ centers or less, if local codes so require:

Special attention must be paid to weatherproofing the points at which the collector loop penetrates the roof. Use quality sealants (e.g. polysulphide or plastic roof cement such as Henry's \#208). For penetrations through flat roofs, it is advisable to use roof jacks. NOTE: Before sealing the roof penetrations, run the roof sensor lead through the penetration closest to the high point of the collector loop.

NOTE: Some pipe insulation (e.g. Armstrong Armaflex) is not suitable for external applications. It may be weatherproofed with a quality external latex paint.

\subsection{CASCADE AUTOCONTROL}

3.5.1 The Autocontrol Unit: After setting the three function switches to the center OFF position, remove the autocontrol cover by releasing the cover retaining screws on each side of the unit. Install the unit out of the direct exposure to the weather or steam exhausts, using two wood screws or bolts as appropriate. The unit should be located close to one of the two tanks, and at eye level if possible.

IOM MANUAL 

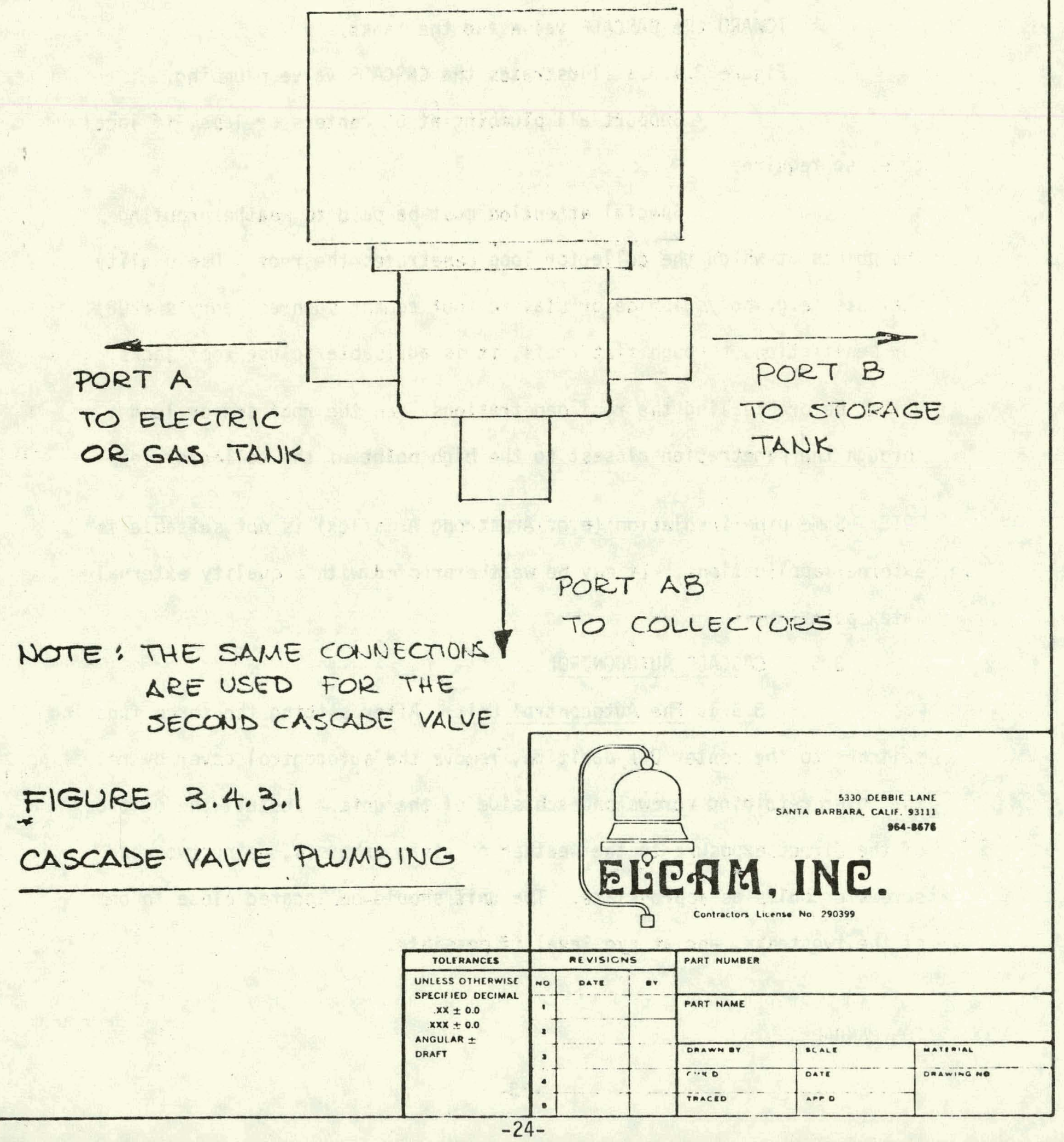


\subsubsection{The Low Voltage Electrical Leads: Connect the}

four low voltage leads as indicated in Figure 3.5.2.1. Gently insert the gromets into their strain relief grooves and then couple the spade terminals appropriately. Note that these leads may be lengthened by splicing the required additional length of 22 gauge 3 strand (red, black and white) cable. WARNING: Maintain the color coding whenever joining the low voltage leads. Note that while each sensor lead terminates in four wires, the yellow (trim resistor) wire is only a few inches in length.

Replace the cover taking care not to bend the lights or switches. Tighten the cover retaining screws and return the three function switches to their AUTO positions.

3.5.3 The Power Supply*: Couple the power supply enclosure to the pump as shown in Figure 3.5.3.1. Run a 110 VAC conduit to the enclosure as shown in Figure 3.5.3.1. This figure also shows how, in the case of a conventional electric tank, the 220 VAC tank supply is routed first to the relay enclosure, and then into the electric tank elements. The low voltage control cable from the autocontrol unit is connected by wire nuts to the low voltage side of the power supply. Although the wiring connections are coded and self evident, Figure 3.5.3.2 illustrates each connection in detail.

3.5.4 The Sensors: The collector sensor is mounted on the higher (exhaust) pipe of any convenient collector. This sensor must be securely attached with a stainless steel worm gear clamp as shown in Figure 3.5.4.1. The head of this sensor must contact the grommet in the collector box. It is essential that this sensor be adequately insulated * WARNING: OPEN ALL WATER HEATING ELECTRIC CIRCUITS PRIOR TO WORKING ON ANY ELECTRIC WATER HEATER. IOM MANUAL 
IPRINTED

CIRCUIT

BOARD

outune

YELLOW RED YELLOW RED YELLM FED EIACK RED

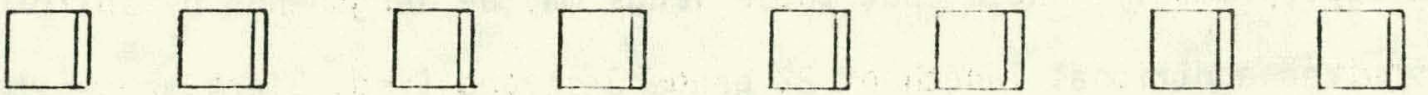

WHITE BLACK WHITE BLACK VUHE BLAK NHITE NOT USED
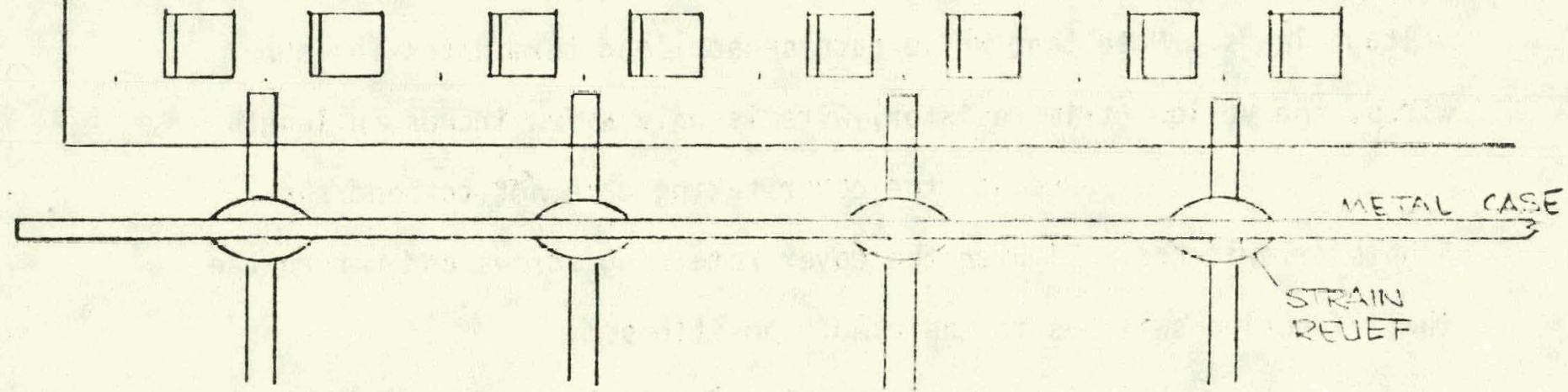

$T_{C}$-COLLECTOR $T_{E}$-ELECTEIC ISSTO:GE CSADE

ALVE DELAY

FIGURE 3.5.2.1 CONTROL LEAD COXXR CODWG

NOTE :

YELLOW - TRIM

RED - SIGNAL

WHITE - GROUND

* BLACK - + gVOLTS

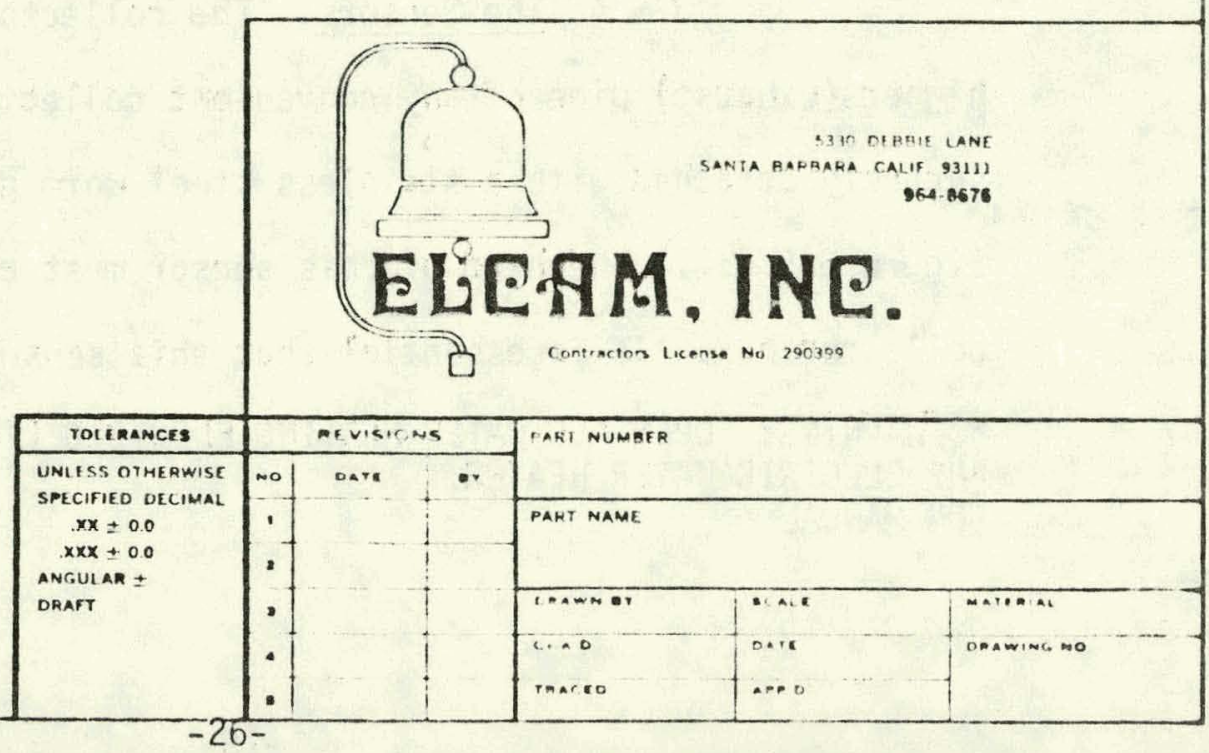




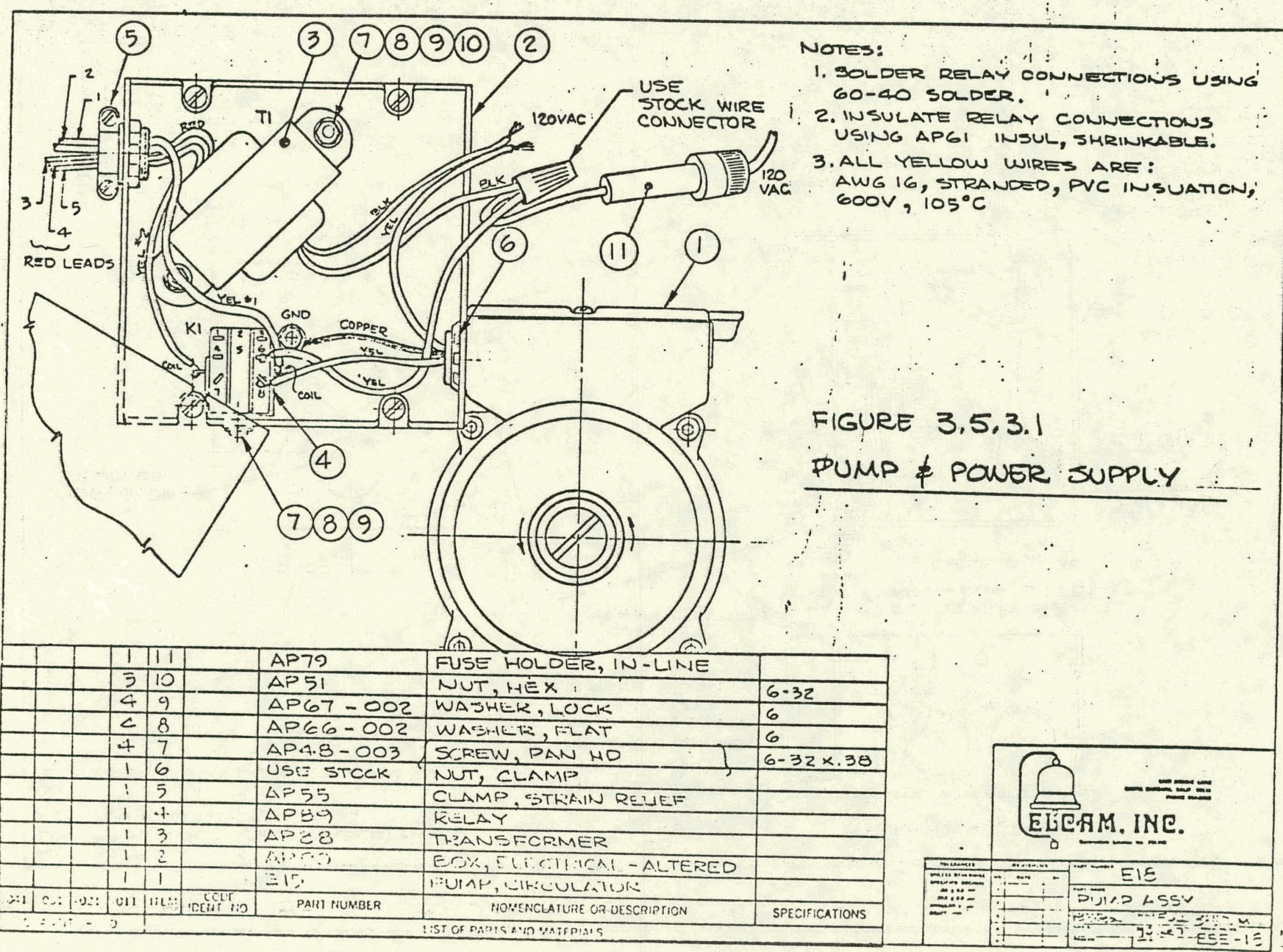




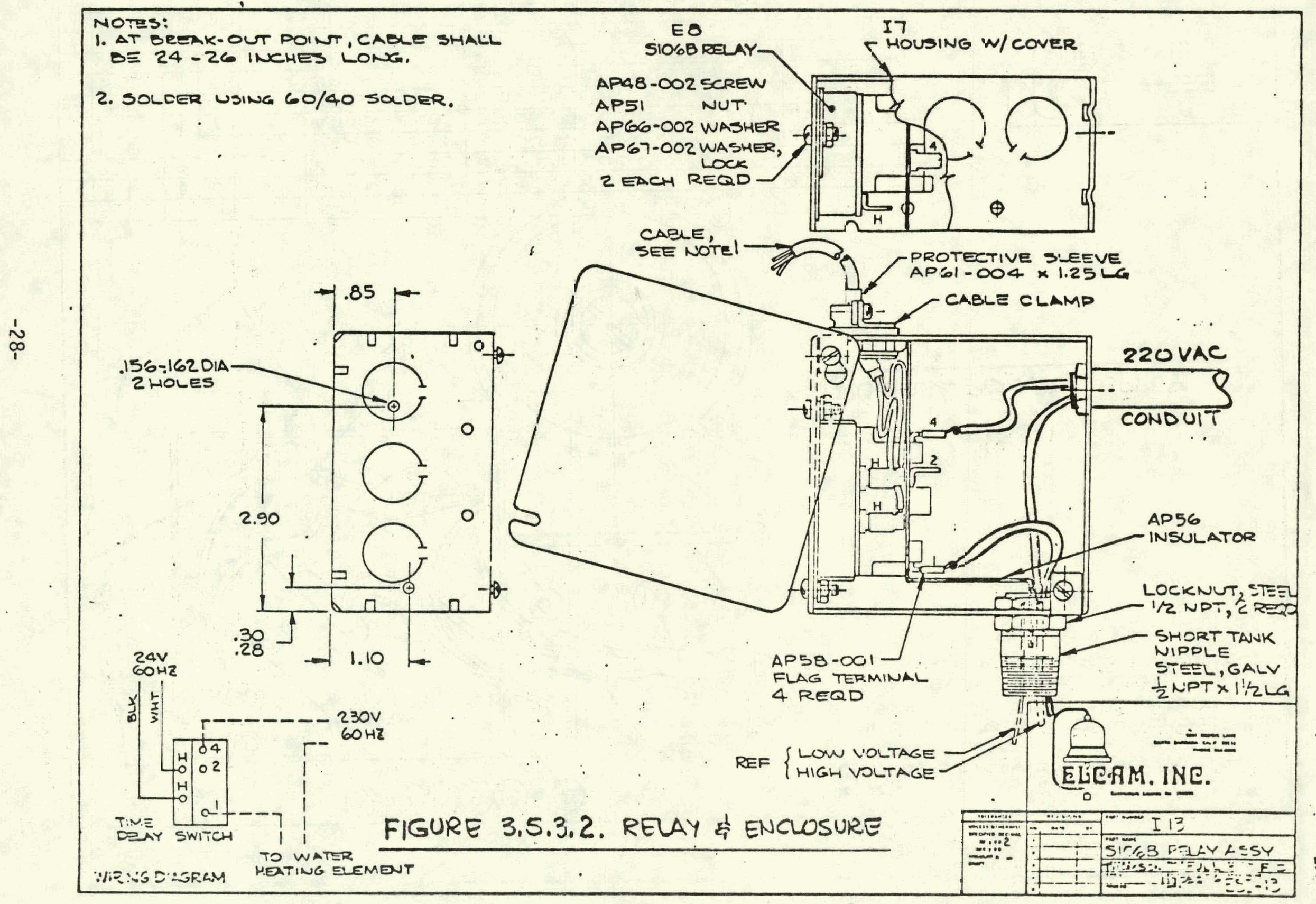




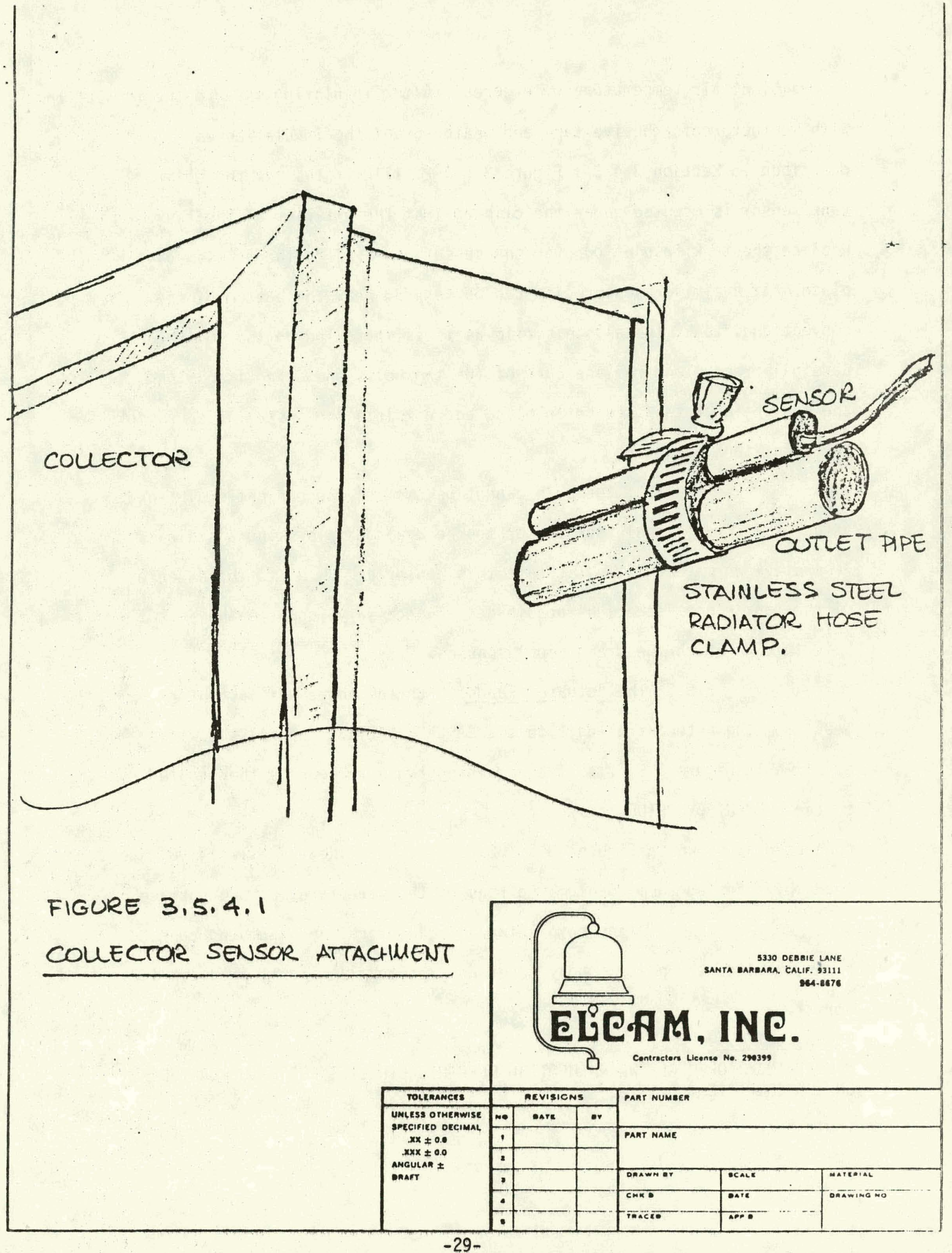


from ambient air temperature or breezes: After insulating, secure the insulation with weatherproof adhesive tape and weatherproof the insulation as described in Section 3.4.3. Figure 3.5.4.2. illustrates how the solar tank sensor is mounted under the clip against the exterior of the tank. Replace the tank insulation over the sensor and replace the access cover plate. If a similar sensor clip can be secured near the bottom of the conventional tank, install this clip as it is installed on the solar tank. Carefully remove and replace each of the two bolts one at a time. Snap the conventional tank sensor in place and complete the installation as for the solar tank sensor.*

If the clip cannot be used on the conventional tank, attach the conventional tank sensor to the drain nipple using a stainless steel worm gear clamp. Locate this sensor as close to the exterior of the tank ( not jacket) as possible. If necessary, enlarge the jacket hole through which the drain nipple passes.

\subsubsection{The Actuator Leads: Run the three wire actuator} lead from the autocontrol unit to the CASCAUE VALVE. Connect the wires as shown in Figure 3.6.5.1. The remaining two wire lead is then routed to the ELEMENI OVERRIDE reilay and connected as shown in Figure 3.5.32. Neaten all low voltage leads by securing them to plumbing runs or the structure, as appropriate. After completing all electrical and plumbing connections, replace the power supply cover and return all circuit breakers to normal.

* WARNING: OPEN ALL WATER HEATING ELECTRIC CIRCUITS PRIOR TO WORKING ON ANY ELECTRIC

IOM MANUAL 


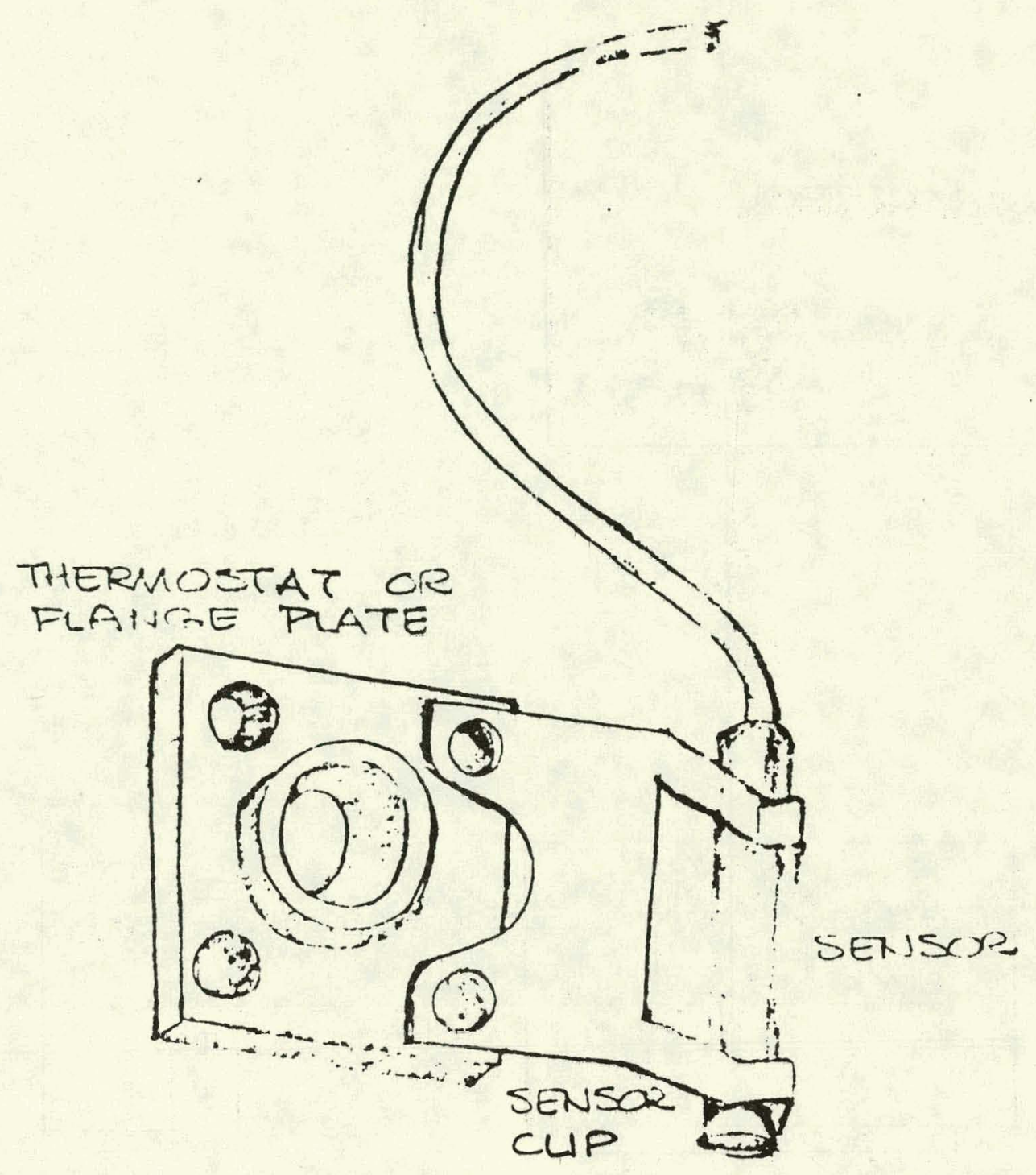

FIGURE 3.5.4.2. TANK SENGOR MOUNTINE.

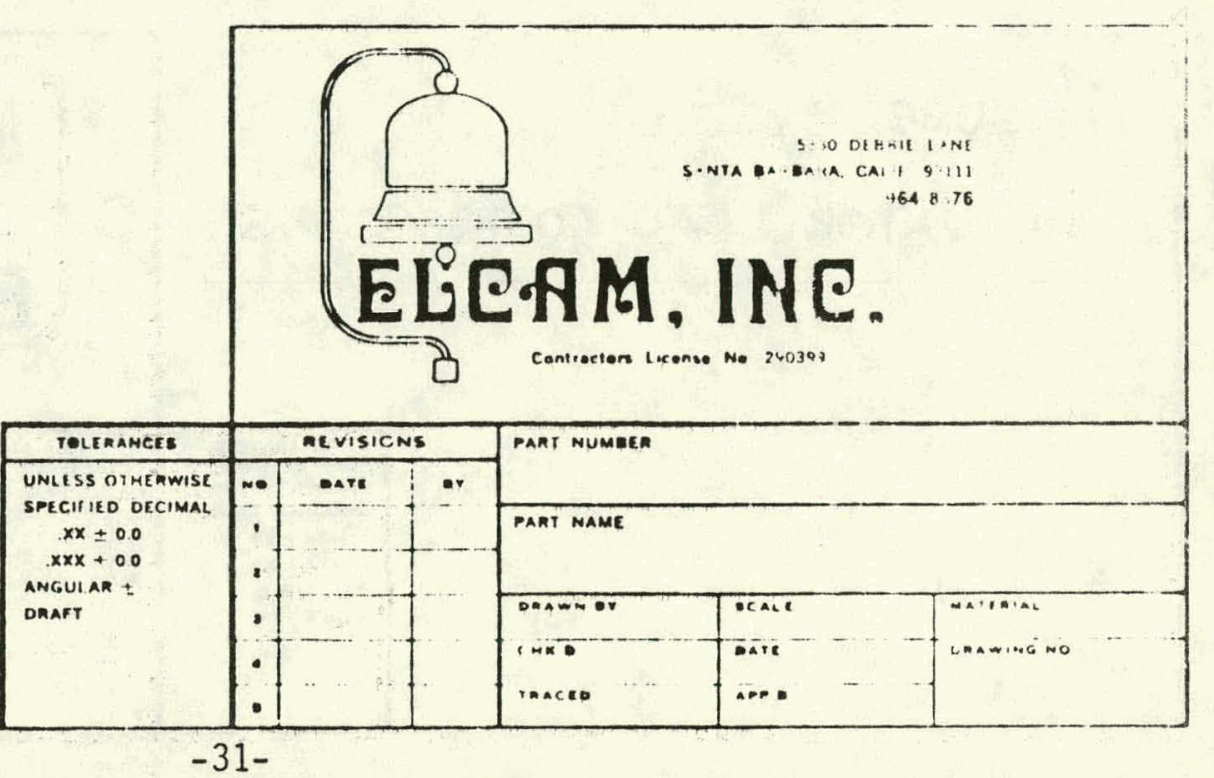




\section{AUTOCONTROL}

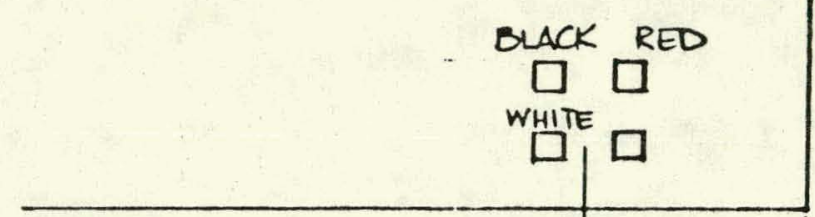

FIGURE 3.6 .5 .1

actuator lead color coding

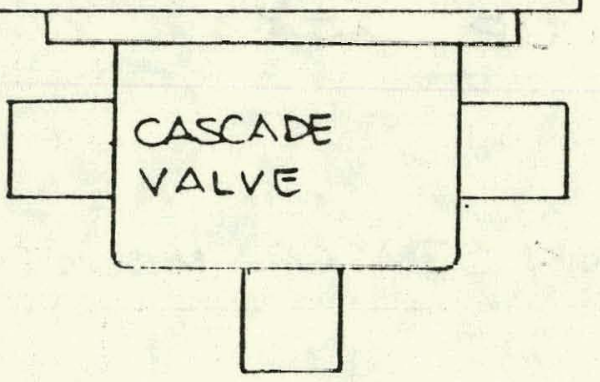

I HEATER

D RELAY

I

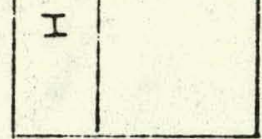




\subsection{Freeze Control.}

SUNSPOT Installations in cold climates must be protected against freeze damage by specifying the FREEZE CONTROL option for the CASCADE Autocontrol. A cold climate is defined as one in which either (or both) of the following criteria apply:

a. The temperature drops below $32^{\circ} \mathrm{F}$. for more than 30 days each year.

b. The minimum annual temperature may be expected to be be low $25^{\circ} \mathrm{F}$.

3.7.1 Freeze Control Components: The FREEZE CONTROL option includes additional electronics built into the CASCADE autocontrol, a special freeze control vavie, a pressure sensitive electronic switch, a vacuum relief valve; and a teflon seated check valve.

\subsubsection{Freeze Control Operation: If the collector temper-} ature $\left(T_{C}\right)$ approaches freezing $\left(T_{F}\right)$, the FREEZE CONTROL electronics send a pulse to the freeze control value. The valve repositions to isolate the collector loop from the mains pressure, andopens a drain line, into which the collector fluid flows. When $T_{C}$ approaches $i$ ts normal operating range, a second pulse returns the valve to its normal operating position. The collector loop automatically fills and vents.

In the event of a power failure, the autocontrol behaves as if $T_{C}$ were approaching $T_{F}$; and activates the drain cycle. In the event of a mechanical failure of the value, the collector loop would remain 
pressurized. This pressure would close the pressure sensitive switch thereby enabling the FROST CYCLE freeze protection circuits provided as standard in each CASCADE autocontrol. In, this case, as $\mathrm{T}_{C}$ approached $T_{F}$, the pump would circulate, warm or hot water through the collector(s).

\subsubsection{Installing FREEZE Control: The autocontrol unit} is installed in a standard manner. The two additional electrical leads will be connected (as labelled) to the freeze control valve and pressure switch.

The following should be noted.

a. The air vent value on the roof is replaced with the vacuum relief valve. Unscrew the dir vent dust cap by about 1 full turn.

b. . A bleed line is installed between the collector feed and return lines, just inside the building envelope.

c. The bileed line drains toward the collector feed line and includes the teflon seated check value, ortented horizontally, to permit flow toward the collector feed line.

d. The bleed line also includes a TEE immediately adjacent to the collector return line. The air vent valve is installed in the branch of this TEE in a vertical orientation.

e. The pressure switch is installed in the collector feed line immediately below the bleed line TEE.

IOM MANUAL 
f. The FREEZE CONTROL valve is installed in the collector feed line, immediately below the pressure switch. The pump is connected to port "P", port "A" is connected to the pressure switch and port " $E$ " is connected to the drain line.

9. The bleed line, check valve and freeze control valve must be firmly attached to the structure.

h. Connect the 3-wire color coded autocontrol lead to the three freeze control valve leads. Connect like colors.

i. Connect the 2-wire autocontrol lead to the pressure switch. These leads are not polorized.

\subsection{SUNSPOT Single Tank Installation}

In those cases in which only one tank may be used, a SUNSPOT

SINGLE installation is specified. This differs from the standard SUNSPOT DUAL installation in only the following details:
a. The CASCADE VALVE is deleted and the CASCADE VALVE circuit becones inoperable.
b. The check valve in the conventional tank drain line is deleted.
c. The solar tank sensor is deleted.

IOM MANUAL 


\subsection{DUAL CASCADE. VALVES}

A head differential will result between the conventional

and solar tank drain.lines whenever the tops of these tanks are at different elevations. In these cases, a second CASCADE VALVE, is specified to prevent unwanted water flows. The second CASCADE VALVE replaces the TEE in the drain lines between the conventional and solar storage tanks, and it is plumbed and wired in phase with the standard CASCADE VALVE as rulluws:
a. Connect the conventional tank drain to port "A".
b. Connect the solar storage tank drain to port "B".
c. Connect port "AB" to the pump suction line.
d. Connect a 2-wire lead from the standard CASCADE VALVE to the second CASCADE VALVE. Since it is an $A C$ motor, there is no electrical color coding required for connecting the second CASCADE valve.

WARNING; PLACE CONTROL LEVER IN MANUAL POSITION PRIOR TO SWEATING. 


\subsection{OPERATING INSTRUCTIONS}

The SUNSPOT.CASCADE System normally operates completely automatically. If the three function switches are each set to their AUTO position, solar energy will be used in preference to conventional energy whenever it is available.

For extended periods of zero hot water demand, (e.g. vacations or more than two or three days) the OFF position may be selected for the HEATER OFF switch. This will prevent any use of conventional energy, while providing solar heated water when it is required.

For maximum conventional energy conservation, large hot water demands (e.g. washing machine and dishwasher) should be made only when the POWER, PUMP and HEATER OFF lights are ON. The state (ON or OFF) of the CASCADE light will not affect the degree of conventional energy conservation during a large demand.

Start up procedure is identical for all SUNSPOT Systems. After insuring that both tanks are filled with water (by venting each tank manually through the $P / T$ valves), the electrical circuits may be turned ON. Open both stop cocks in the pump flanges to permit automatic filling and venting of the collector loop. Select the ON position for the autocontrol power switch, and AUTO for the three function switches.

To drain the collector loop, shut the system down by selecting autocontrol and heating power OFF. Close the cold water supply. Place the CASCADE valve lever(s) in MANUAL, and open the collector loop drain valve. When the tank feed lines have drained, close the four shut off gate valves.

IOM MANUAL 
For systems not fitted with the five gate valves mentioned in Section 3.4, a drain line will have to be cut to permit draining. In this case, both tanks will drain. in addition to the collector roop:

Systems equipped with the FREEZE CONTROL option will drain automatically by allowing air to enter the collector loop through the vacuum relief valve. 'In standard systems, the air vent valve will usually provide sufficient vacuum relief for adequate drainage. Faster drainage can be provided by opening the manual control on the collector loop pressure relief valve.

In order to restore a conventionaliy. fired hot water supply after a drain down, close the collector loop drain valve and open the cold. water supply valve. Vent both tanks manually and then restore gas or electricity to the conventional tank.

IOM MANUAL 


\subsection{MAINTENANCE}

SUNSPOT Systems have been developed to require no periodic maintenance. It is possible, however, that individual components may fail and require replacement or repair: This should normally be performed by an authorized SUNSPOT maintenance technician,

If a system malfunction is suspected, the system may be shit down by following the shut down procedure outlined in the previous section. 
This document is intended to analyse the hazards associated with the installation, operation and maintenance of SUNSPOT CASCADE solar systems. Potential and existing hazards to personnel, equipment and structures are identified. In each case, the control or elimination of the hazard is discussed. Hazards are classified as MINOR if the damage or infury that might result is less than serious. MAJOR hazards are those that could result in serious injury or damage. In some cases, a known hazard is accepted. These hazards are known as RESIDUAL HAZARDS and the rationale for their acceptance is provided.

Where hazards result from the failure of equipment or system components, the failure mode and redundant. or hark up safety features are described.

Six sections cover Pressure, Electrical, Toxicity, Flammability, Gas Systems and Hot Water/Steam hazards. Each system is summarized by a CONCLUSION statement. While this document reports on all of the known hazards, no warranty of completness is either given or implied. 
1. PRESSURE

System pressures generally fluctuate as a function of system temperature. In heat exchanger systems, the collector loop pressure rise is tempered by an expansion chamber containing air. Direct heating systems operate at supply or street pressures. The collector temperature increase is generally limited to street pressure which seldom exceeds $100 \mathrm{psi}$. Since the tank, copper pipe and associated fitting design pressures are 150 psi or greater, préssure fluctuations up to street pressures present no hazard.

In one case, however, syștem pressure could exceed street pressure during normal operation of direct systems when the CASCADE valve is energized, it, and the tank cross-over check valve isolate the collector loop and service hot water lumbing from the supply. Significant temperature increases could result in significant pressure increases in both the collector loop and the service hot water plumbing. During normal operation, however, the highest observed pressure has been less than 100 psi.

A failure mode could exacerbate this condition however: should the pump fail while the CASCADE valve is held ON, it is pessible that the water in the collector might boil. If this were to occur, and if the system pressure increased to 125 psi, two pressure relief valves, each set to open at $125 \mathrm{psi}$, would relieve the overpressure. It 
should be noted that a power failure would not produce the failure modes described in this paragraph, since power is required to maintain the CASCADE valve ON.

In the event that all safety devices fail simuitaneously, naturally limiting influences apply. At 124 psi, the boiling temperature of water is $343.7^{\circ} \mathrm{F}$. Thus as the temperature and pressure increase, the potential for steam generation is naturally limited. Mark's Standard Handbook for Mechanical Engineers indicates a pressure rise of about 125 psi for sleailii genteraled at about $350^{n} \mathrm{~F}$.

Excess pressure which would result from freezing is guarded against by the autocontrol's frost cycle or a collector dump tank system; whichever is appropriate. Should either safety system fail for any reason, the hazard would be limited to the collector waterways which would probably crack.*

CONCLUSION: NO PRLSSURE HAZARD EXISTS.

\section{Electricity}

Three levels of voltage are used in SUNSPOT systems:

1. 220 VAC drives the electric element.

*Note: An interesting passive freeze protection.system deserves attention. The introduction into the waterways, of a flexible tube (whose flexibility was retained at freezing temperatures) would permit repeated collector freezing without damage to the waterways. 
2. 110 VAC drives the pump and autocontrol.

3. 24 VAC drives the CASCADE valve and heater relay." This voltage presents no hazard.

During installation, the normal safety precautions usually observed (opening circuit breakers) will preclude any danger of electrical shock. Proper installation of each of the standard insulating barriers and ground leads minimize the danger of shock during routine maintenance. Covers, isolation and ground leads preclude any danger of shock during normal operation.

CONCLUSION: - A MAJOR HAZARD EXISTS WITH RESPECT TO INSTALLATION AND MAINTENANCE PERSONNEL. THIS HAZARD IS CONTROLLED AND/OR ELIMINATED BY OBSERVATION OF STANDARD PROCEDURES AND BY USE OF APPROPRIATE INSULATORS, COVERS AND GROUND CONNECTIONS. NO RESIDUAL HAZARD EXISTS WITH RESPECT TO NORMAL OPERATION.

3. TOXICITY

Two forms of toxicity might result from the installation and use of a DWH system. The potable water supply might be polluted and toxic fumes might be generated by the system during normal operations, installation, or during a fire. 
Potable water drawn from the public supply (or a private suppliers well, river course or spring, etc.) is the only fluid introduced into SUNSPOT systems: All materials with which the water comes into contact are approved for use in potable water systems by the California State Health Department. These materials include:

- copper

- brass

- nylon and rubber (gaskets and valve inserts)

- magnesium anorte

- Stainless steel (dip tube)

- other materials detailed in Document ESC-7g An uninformed owner might add a toxic fluid (e.g. antifreeze solution) to the collector loop in heat exchanger systems. If a heat exchanger leak occurred the potable water could be polluted. It is our opinion that double walled heat exchangers will not remove the reason for, or cause of, such a leak. There is little that a manufacturer can do to preclude the hazardous use of its products, other than placarding and printing precautions and warning.

Toxicity resulting from fumes during installation must be guarded against by adequate ventillation. Fire appears to produce no toxic fumes from any of the flmmable materials. See Section 4: Flammability.

CONCLUSION: NO TOXICITY HAZARD EXISTS. 


\section{FLAMMABILITY}

The exposed metalic surfaces used in SUNSPOT Systems include aluminum, copper, brass and zinc-coated steel. None of these are flarmable.

Fhe exposed non-metallic materials include:

- Tedlar/acrylic sandwich - collector cover

- Rubber - pipe insulation

- Latex paint - exterior pipe insulator coating

- Vinyl - electrical insulation

- Goodyear Flame Resistant ABS - Autocontrol cover

Each of these is covered below:

Tedlar/acrylic sandwich - Flammable. Ignites with cigarette lighter.

Flame propagates at 1.82 inches per minute.

Rubber insulation - Flammable. Ignites with propane torch. Self extinguishing horizontally and vertically.

Latex paint - Flammable. Ignites with cigarette lighter. Manufacturer (Sherwin-Williams) claims $3 B$ flammability rating. f.e. Paint will not ignite with torch. Our tests indicate this is not.so. When paint fuel is consumed, rubber insulation on which it was applied becomes blisterred, but does not ignite.

Vinyl electrical insulation - Flammable. Ignites with cigarette lighter. Self extinguishing horizontally and vertically. Goodyear Flame Resistant ABS - Flammable, Ignites with cigarette lighter. Self extinguishing horizontally and vertically. 
The collector side and back insulation is urethane foam which is flammable. "The closed cell vinyl gasket and double backed adhesives are also flammable." Becaüse these component's are completely with in the collector enclosure, its flammability hazard is considered to be less than minor.

CONCLUSION: A LESS THAN MINOR FLAMMABILITY HAZARD EXISTS WITH RESPECT TO PERSONNEL, EQUIPMENT AND STRUCTURES. SINCE THESE HAZARDS ARE EQUIVALENT TO; OR LESS THAN THE FLAMMABILITY HAZARDS COMMON TO STANDARD RESIDENTIAL CONSTRUCTION. THESE HAZARDS ARE ACCEPTED.

\section{GAS SYSTEMS}

In many cases gas tanks (natural or propane) will become a constituent part of SUNSPOT CASCADE sy'stems. Since the CASCADE autocontrol cannot command the gas value, the gas system will not be interfered with in anyway. A yas vaive actuator will be developed.

CONCLUSION: NO' GAS HAZARD EXISTS.

6. HOT WATER AND/OR STEAMM

Scalding water and/or steam present a potentially major hazard to personnel during installation, maintenance, and even normal operation. Normal operating temperatures often exceed $160^{\circ} \mathrm{F}$. and a bare copper pipe at this temperature can cause a first degree skin burn. The opportunity to inadvertantly contact bare copper pipes is greatly 
reduced through the use of heavy rubber insulation around all exposed pipes. Valve bodies are generally not insulated, however, so this hazard remains to some extent. Becuase the valve bodies are small, and becuase they are usually placed in less than casually accessible positions, this minor hazard, is accepted.

During installation and/or maintenance, or whenever the pump is inoperative during high rates of insolation, the collector temperature may exceed $212^{\circ} \mathrm{F}$. Water in the collector may become steam: Any openings in the collector loop can thus, become the source of a jet of scalding water mixed with steam.: To reduce the hazard of being exposed to such a jet, the following precautions are recomended:

1. Keep children and pets away from valves and unfinished plumbing connections during installation or repair.

2. Remove valve handles after system is returned to service, and store them beyond the reach of children.

3. Keep collector covered with cardboard or other opaque material (taped in place) during installation and maintenance.

4. Install collectors to permit good drainage.

5. Drain collector loop thoroughly prior to cutting into loop.

6. When draining collector loop in heat exchanger models, use a hose to take the effluent from the drain valve to a safe location such as a street gutter or storm water drain. Direct systems drain through the tanks and are thus not hazardous. 
7. Remain clear of the pressure relief valve drain normally" installed in the vicinity of the collectors.

CONCLUSION: A MINOR PERSONNEL HAZARD EXISTS WITH RESPECT io COH. TACTING BARE COPPER OR BRASS SURFACES WHICH ARE HEATED BY HOT WATER OR STEAM. THIS HAZARD IS RENDERED ACCEPTIBLE BY INSULATION AND BY LOCATING UNINSULATED SURFACES REMOTELY.

A MAJOR PERSONNEL HAZARD EXISTS WITH RESPECT TO SCALDING WATER AND/OR STEAM JETS. THIS HAZARD EXISTS AS A RESULT OF THE FUNDAMENTAL PHYSICS OF A GOOD SOLAR COLLECTOR. CONSEQUENTLY THIS HAZARD CANNOT BE ELIMINATED. IT IS RENDERED ACCEPTABLE BY OBSERVING THE LIST OF RECOMMENDED PRECAUTIONS. 